\title{
Why female board representation matters: The role of female directors in reducing male CEO overconfidence
}

\author{
Jie Chen $^{\dagger}$ \\ Leeds University Business School, University of Leeds \\ Maurice Keyworth Building, Leeds LS2 9JT, UK \\ J.Chen3@leeds.ac.uk \\ Woon Sau Leung \\ University of Edinburgh Business School, University of Edinburgh \\ 29 Buccleuch Place, Edinburgh EH8 9JS, UK \\ WoonSau.Leung@ed.ac.uk \\ Wei Song \\ Southampton Business School, University of Southampton \\ Highfield, Southampton SO17 1BJ, UK \\ w.song@soton.ac.uk \\ Marc Goergen \\ IE Business School, IE University \\ María de Molina 12, 28006 Madrid, Spain \\ Marc.Goergen@ie.edu \\ and \\ European Corporate Governance Institute \\ Brussels, Belgium
}

This version: June 2019

\footnotetext{
$\dagger$ Corresponding author. Leeds University Business School, University of Leeds, Maurice Keyworth Building, Leeds, UK, LS2 9JT; E-mail address: J.Chen3@leeds.ac.uk.

We are grateful for helpful comments from Renée Adams, Francesca Cornelli, Ali Akyol, Daniel Ferreira, Julian Franks, Jens Hagendorff, Iftekhar Hasan, Nadia Massoud, Khelifa Mazouz, Neslihan Ozkan, Cheng Zeng and seminar participants at the University of Bristol, Cyprus University of Technology, Cardiff Business School, IE Madrid, Durham University, University of Trento, Leeds University Business School, the 2016 Xiamen-Cardiff Symposium, the 2017 Financial Institutions, Regulation and Corporate Governance Conference, and the IFABS 2017 Ningbo China Conference. All errors are our own.
} 


\title{
Why female board representation matters: The role of female directors in reducing male CEO overconfidence
}

\begin{abstract}
We suggest a novel reason why there might be a need for female board representation. Female participation in the boardroom attenuates the CEO's overconfident views about his firm's prospects as we find that male CEOs at firms with female directors are less likely to hold deep-in-the-money options. Further, we argue that female board representation matters for industries where male CEO overconfidence is more prevalent. We find support for our argument as female directors are associated with less aggressive investment policies, better acquisition decisions, and improved financial performance for firms operating in industries with high overconfidence prevalence. We also identify a market failure around economic crises. Firms that do not have (sufficient) female board representation suffer a greater drop in performance as a result of the crisis than those that have female board representation.
\end{abstract}

JEL classification: G30, G32, G34

Keywords: Female board representation; CEO overconfidence; Investment; Firm performance 


\section{Introduction}

A rapidly growing literature suggests that female directors have a significant impact as they are associated with fewer employee layoffs (Matsa and Miller, 2013), lower propensity to initiate acquisition bids as well as lower bid premiums (Levi et al., 2014), higher research and development (R\&D) expenditures (Miller and Triana, 2009), better firm reputation (Hill and Jones, 1992; Heugens et al., 2004), increased ability to reflect stakeholder interests (Rindova, 1999; Carter, 2006), improved stock price informativeness (Gul et al., 2011), more equitybased pay for directors and higher CEO turnover-performance sensitivity (Adams and Ferreira, 2009). Still, gender differences in behavior (see Croson and Gneezy, 2009, for a review) alone may not necessarily lead to female directors having an impact because they tend to be minorities in the boardroom (Adams and Ferreira, 2009). This begs the question as to why female directors are so influential. We attempt to answer this question by studying whether female board representation affects the beliefs and behavior of the CEO, who typically has the greatest influence on corporate decision making. Specifically, we examine whether the option exercise behavior of the CEO, an indicator of the CEO's degree of overconfidence, is affected by female board representation.

The CEO's option exercise behavior provides an ideal setting to answer our research question. First, stock options are an important component of executive compensation (Hall and Murphy, 2002). Therefore, the option exercise and its timing are important aspects of the CEOs' management of their individual wealth. Second, CEOs' personal portfolio decisions are indicative of their beliefs about future firm performance. Previous literature suggests that CEOs who voluntarily hold deep-in-the-money options are likely to be overconfident of their ability to keep their company's stock price rising, which induces them to postpone option exercise in order to gain from the expected price increases (Malmendier and Tate, 2005; Malmendier and Tate, 2008; Malmendier et al., 2011). Third, unlike corporate decisions made by the top 
management team that likely reflect the team's collective beliefs, option holding and exercise decisions made by the CEOs themselves are more likely to reveal their individual beliefs. Hence, CEOs' option exercise behavior is an excellent laboratory to investigate the following question: Does female board representation help reduce managerial overconfidence?

We focus on CEOs because overconfidence is likely to be more prevalent among CEOs (Goel and Thakor, 2008; Graham et al., 2013). They are also the principal decision-maker within the firm. Their biased beliefs due to overconfidence (Malmendier and Tate, 2005; Malmendier and Tate, 2008; Malmendier et al., 2011) are therefore likely to have a notable influence on firm decisions and performance. In turn, female directors may affect corporate outcomes through moderating the CEO's biased beliefs.

To test whether female directors reduce male CEO overconfidence, we follow Campbell et al. (2011) and Hirshleifer et al. (2012) in calculating the moneyness of CEOs' option portfolios (i.e., the extent to which the stock price exceeds the exercise price) for each year and use it to capture their levels of (over)confidence. Holding onto options that are already deep in the money is considered evidence of overconfidence about the company's prospects, drawing upon the rationale proposed by Malmendier and Tate (2005), Malmendier and Tate (2008), and Malmendier et al. (2011).

We find a negative and significant effect of the representation of women on boards, as measured by the fraction of female directors, on the level of option moneyness for male CEOs. Interpreting option moneyness as a proxy for overconfidence suggests that male CEOs at firms with female directors are less likely to exhibit overconfidence. As expected, the effect of female representation is statistically insignificant for female CEOs, suggesting that the observed negative effect on male CEO option moneyness likely reflects differences in gender.

Having established a negative effect of female board representation on the extent of the CEO's overconfidence, we attempt to identify the circumstances under which this effect has 
an impact on corporate decisions, and ultimately performance. It is evident from the literature that too much overconfidence is detrimental to the firm because it leads to overly optimistic views about investment opportunities, resulting in overinvestment, financial constraints, and bad acquisition decisions (Malmendier and Tate, 2005; Malmendier and Tate, 2008; Malmendier et al., 2011; Banerjee et al., 2015). Therefore, by reducing CEO overconfidence, female board representation may result in less aggressive investment policies and better acquisition decisions. If this were to be the case, this would make board gender composition particularly important in industries in which CEOs are more likely to develop overconfidence. The effects of female board representation on corporate decisions should then be stronger in these industries. We find evidence in support of this argument as female board representation is associated with less aggressive investment policies, better acquisition decisions, and ultimately improved firm performance in industries with high overconfidence prevalence. There is no such effect in industries with low overconfidence prevalence.

Importantly, we examine whether female board representation explains the crosssectional heterogeneity in firm performance during the financial crisis of 2007-2009. Managerial overconfidence is likely associated with poor performance during the crisis because it may lead CEOs to pursue aggressive strategies that ex post make their firms more vulnerable to the crisis (Ho et al., 2016). If female directors are more likely to caution against an overly optimistic assessment of investment prospects during noncrisis years, then the subsequent financial crisis should represent less of a shock for CEOs with female directors on their boards than for those without. The results are consistent with this prediction. We find that greater female board representation is associated with a smaller reduction in CEO option moneyness during the crisis. This finding suggests that, being cautioned against overconfident views about the firm's prospects during noncrisis years, CEOs of firms with female board representation appear to be less affected by and adjust their personal portfolios less substantially in response 
to the crisis. We also find that female board representation reduces the negative impact of the crisis on firm performance, consistent with CEOs of firms with female board representation adopting less aggressive strategies that make their firms less vulnerable to the crisis.

Our paper makes three major contributions to the extant literature. First, it contributes to the literature on board gender composition (see e.g. Adams and Ferreira, 2009; Gul et al., 2011; and Levi et al., 2014) by suggesting a novel channel whereby women affect firm decision making. We find that this channel is the moderating effect of women on potential male CEO overconfidence. Hence, we add to the debate over whether board gender diversity affects firm performance. The literature is as yet divided with Campbell and Minguez-Vera (2008), Liu et al. (2014), and Bennouri et al. (2018) documenting a positive effect, Ahern and Dittmar (2012) documenting a negative effect, and Farrell and Hersch (2005) finding an insignificant market reaction to the announcement of a female appointment to the board. Our results suggest that the firm's industry matters as female board representation is particularly valuable in industries with high CEO overconfidence prevalence.

Second, this paper adds to research on the types of firms that perform better during a financial crisis. Lins et al. (2017) show that firms with more social capital were perceived to be more trustworthy and received a greater value premium and stakeholder support during the 2007-09 crisis. In this paper, we show that firms with female directors experience a less substantial drop in performance during the crisis. Specifically, our paper complements prior studies by showing that the moderating effect of female directors on male CEO overconfidence explains part of this cross-sectional heterogeneity in firm performance.

Third, our paper also contributes to the literature on whether overconfidence is more likely in certain types of decision-making environment. For instance, field research suggests that individuals are more prone to overestimating outcomes to which they are highly committed (Weinstein, 1980) and when the feedback they receive is delayed or ambiguous (Nisbett and 
Ross, 1980; Simon and Houghton, 2003). More recently, Kolasinski and Li (2013), and Banerjee et al. (2015) find that board monitoring improves decision making by overconfident CEOs. Our findings extend this line of inquiry by showing that male CEOs are less likely to exhibit overconfidence when there is a greater representation of women on their boards.

Our paper has two important policy implications. First, it suggests that female board representation matters more in certain industries than others. Industries where female board representation creates value via reducing male CEO overconfidence include pharmaceuticals, computer software, coal, and construction. Second, our findings suggest a market failure around periods of economic crisis. Firms that do not have (sufficient) female board representation suffer a greater drop in performance as a result of the 2007-2009 crisis than those that have female board representation.

The rest of the paper is organized as follows. The next section explains why female directors may have an impact on firm decisions despite their relatively low representation on boards. Section 3 describes the sample, model specification, and measurement of variables. Section 4 discusses the main results and addresses identification issues. Section 5 examines whether the effect of female board representation on corporate decisions and firm performance varies across industries. Section 6 investigates whether firms with female directors perform better during the 2007-2009 crisis. Section 7 tests the robustness of our results. Section 8 concludes.

\section{Why are female directors so influential?}

As female directors typically are in a minority, why would they have a significant effect on firm decision making, and ultimately firm performance? Membership of an underrepresented group does not preclude one from influencing managerial decision-making processes (Westphal and Milton, 2000). Bordalo et al. (2012) argue that the salience of part of the 
environment attracts our attention and that the information from that part receives a disproportionally greater weight in decision making. They cite Kahneman (2011:324) that "our mind has a useful capability to focus on whatever is odd, different and unusual". More specifically, Hillman et al. (2002), from their survey of the extant literature, conclude that individuals that are visually salient tend to be perceived as being more influential. Hence, given the minority status of women on boards and the mounting pressure on companies to increase board diversity, female directors are likely perceived to be more salient.

In turn, the extant literature suggests that women manifest behavioral and attitudinal differences compared to males. ${ }^{1}$ Importantly, they tend to be less overconfident in their decision making than men (Bellucci et al., 2010; Huang and Kisgen, 2013; Levi et al., 2014). Further, female directors tend to be less conformist and are more likely to exhibit activism and express their independent views than male directors because they do not belong to 'old-boy' networks (Adams and Ferreira, 2009). Hence, a key benefit of having female directors on the board is the improved quality of board deliberations on complex issues by bringing in different and sometimes conflicting perspectives and enriching the information set available to the board (Chen et al., 2005; Miller and Triana, 2009; Gul et al., 2011). The presence of female directors on boards tends to lead to more competitive interactions so that decision-making processes are less likely to be characterized by acquiescence or rapid consensus (Chen et al., 2016). Therefore, a board with female directors more likely pushes the CEO to consider a wider range of alternatives as well as the full set of arguments in favor and against any given alternative. This likely results in a more thorough and realistic assessment of the decision problem and attenuates the CEO's potentially biased beliefs (Paredes, 2005). Hence, we expect that male

\footnotetext{
${ }^{1}$ Beck et al. (2018) provide evidence that not only gender differences but also gender interactions matter as they find that first-time borrowers assigned to loan officers of the opposite sex pay higher interest rates, receive smaller and shorter-maturity loans, and are less likely to return for a second loan.
} 
CEOs at firms with female directors are more likely to be exposed to divergent thinking and, hence, less likely to focus on information confirming their individual judgment, to overestimate the firm's prospects, and to hold options that are deep in the money.

\section{Data, methodology and descriptive statistics}

\subsection{Data}

We utilize several databases to construct our sample. The data on CEO characteristics (e.g., age, tenure, and gender) and option compensation is from ExecuComp. We obtain additional data on CEO careers and education from BoardEx. The data on director characteristics is from IRRC/Riskmetrics. Further, accounting data is from Compustat and stock returns are from CRSP. Financial firms are excluded. The final sample consists of 1,629 firms with 11,437 firmyear observations between 1998 and 2013. There are 11,113 firm-years with male CEOs and 322 firm-years with female CEOs.

\subsection{Methodology}

To explore whether female board participation influences the CEO's option holding and exercise behavior, we estimate the following baseline empirical model:

$$
\text { CEO option moneyness } \begin{aligned}
i, t+1 & =\alpha+\beta \text { Fraction of female directors } i, t \\
& +\gamma Z_{i, t}+\text { Industry }_{i}+\text { Year }_{t}+\varepsilon_{i, t}
\end{aligned}
$$

where CEO option moneyness is the estimated moneyness of the CEO's stock options, which is discussed in detail in the following subsection. The key independent variable of interest, Fraction of female directors, is the number of female directors divided by the total number of directors on the board. $Z$ is a vector of firm, CEO and governance characteristics that potentially affect the CEO's option holding and exercise decisions. Industry ${ }_{i}$ represents industry-fixed 
effects constructed using the Fama and French 49 industry specifications and Year ${ }_{t}$ captures the year-fixed effects.

\subsubsection{Measuring the dependent variable}

The use of the option-based CEO confidence measure is motivated by extant literature linking CEO confidence with their stock option holding and exercise decisions. The rationale is that CEOs are highly exposed to the idiosyncratic risk of their companies as their human capital is undiversified and they typically have a large part of their wealth tied to their firms. Therefore, risk averse, rational CEOs would exercise their stock options early to divest themselves of idiosyncratic risk (Hall and Murphy, 2002). Holding exercisable deep-in-the-money options suggests that CEOs overestimate the returns on their investment projects and postpone option exercise to tap into the expected future gains, suggesting overconfidence (Malmendier and Tate, 2005).

The ExecuComp data used to construct the option-based measure is not as detailed as the proprietary data that Hall and Murphy (2002) and Malmendier and Tate (2005) uses. Thus, we use a modified version of the Malmendier and Tate (2005) overconfidence measure, following Campbell et al. (2011) and Hirshleifer et al. (2012). Specifically, we estimate the average CEO stock option moneyness for each year as follows. We first calculate the average realizable value per option by dividing the total realizable value of the exercisable options by the number of exercisable options. Next, we subtract the average realizable value from the fiscal year-end stock price to obtain the average exercise price of the options. The estimated moneyness of the options is then calculated as the stock price divided by the estimated average exercise price minus one. ${ }^{2}$ As we are interested in the CEO's decisions to hold options that could have been

\footnotetext{
${ }^{2}$ The option moneyness variable is winsorized at the $1^{\text {st }}$ and $99^{\text {th }}$ percentiles to reduce the potential impact of outliers.
} 
exercised, we include only exercisable options held by the CEO. Further, we allow the continuous "CEO confidence" measure to vary over time as overconfidence may vary with past experience and performance (Hilary and Menzly, 2006) and, more importantly, because our paper attempts to examine, among others, whether male CEO overconfidence varies with female board representation.

An alternative measure of CEO beliefs in the future, proposed by Malmendier and Tate (2008), builds on the perception of outsiders. This approach consists of counting articles in the financial press that refer to the $\mathrm{CEO}$ as "confident" relative to the number of articles that characterize the CEO as "cautious". However, we do not use this measure in our study, because it is an indicator variable based on the CEO's press portrayal, rather than the latter's actions, and hence is noisier (Malmendier and Tate, 2008), and fails to capture changes in the CEO's behavior due to the influence of female directors.

\subsubsection{Control variables}

We include several firm, governance, and CEO characteristics that potentially affect CEO overconfidence as measured by their option holding and exercise behavior. We include firm size as talented CEOs tend to work for larger firms to allow their talent to have greater impact (Edmans and Gabaix, 2011), and because managing large, complex firms requires better managerial skills and expertise. Similarly, firms with more growth opportunities have greater scope for talented CEOs to add value and hence are more likely to appoint them (Edmans and Gabaix, 2011; Graham et al., 2013). We measure firm size as the logarithm of sales and growth opportunities by Tobin's q. In turn, talented CEOs are more likely to exhibit overconfidence (Goel and Thakor, 2008). In addition, leverage increases the riskiness of equity-based compensation, and thereby may affect the CEO's decision to hold options. Hilary and Menzly (2006) provide evidence that individuals who have experienced past successes are more likely 
to display overconfidence. Thus, we use both market (Stock return) and operating (Return on assets) measures to proxy for the CEO's prior performance. Controlling for stock returns also helps mitigate the concern that our option moneyness variable may simply be a manifestation of stock performance. To reduce the potential impact of outliers, the above accounting variables are winsorized at the $1^{\text {st }}$ and $99^{\text {th }}$ percentiles.

Banerjee et al. (2015) show that increased board monitoring after the Sarbanes-Oxley Act (SOX) serves to restrain the excesses of overconfident CEOs and improve their decision making. We include three governance indicators suggested in prior studies to account for the restraining effect of governance on CEO overconfidence: the Bebchuk et al. (2009) E index; Board size, which is the number of directors on the board; and Board independence, which is the ratio of the number of independent directors to board size. All firm, governance and board characteristics are lagged one year relative to the dependent variable to mitigate endogeneity concerns.

We incorporate several controls for CEO characteristics because of prior evidence that they are important in determining individual behavior and decision making (Goergen et al., 2015; Bertrand and Schoar, 2003). First, we include CEO age as age consists of a variety of factors that progressively shape an individual's behavior. Agarwal et al. (2009) indicate that the sophistication of financial decisions varies with age. Second, CEO tenure is the number of years the CEO has been in office, and CEO Chairman is an indicator variable that equals one if the CEO also chairs the board, and zero otherwise. Both controls account for possible entrenchment, which may exacerbate biased beliefs (Banerjee et al., 2015). Moreover, we include CEO ownership to avoid entangling the measurement of overconfidence with the potential ownership and incentive implications of stock option exercise.

The final set of controls captures the CEO's professional background, past experience, and education. Graduating from a prestigious university and obtaining an MBA degree may 
reflect innate intelligence and the accumulation of human and social capital (Graham et al., 2013), which could affect CEO behavior and beliefs. Bertrand and Schoar (2003) provide some evidence that CEOs with MBAs behave more aggressively. Ivy League is an indicator variable that equals one if the CEO attended an Ivy League university, and zero otherwise, and $M B A$ is an indicator variable that equals one if the CEO has a Master of Business Administration (MBA) degree, and zero otherwise. Similarly, Age first CEO role, defined as the age at which the CEO became CEO for the first time, is a relevant managerial characteristic as it indicates innate talent. In addition, Qualification is an indicator variable that equals one if the CEO has professional qualifications (e.g., Chartered Financial Analyst, Certified Public Accountant), and zero otherwise. Further, military service during early adulthood has been shown to have a lasting effect on veterans' life-choices and decision making (Elder and Clipp, 1989). Therefore, we include an indicator variable, Military experience, set to one for CEOs with prior military service, and zero otherwise.

\subsection{Descriptive statistics}

Table 1 reports the distribution of female board presence and the average for the option-based overconfidence measure across years and industries. Panel A shows the number and percentage of firm-years with female directors as well as the number and percentage of firm-years with more than one female director, in addition to the average CEO option moneyness across years. Panel B shows the equivalent numbers across industries.

Panel A suggests that, while the percentage of firms with female directors increases during the first half of the period of study, it is relatively stable at about $75 \%$ during 2006-2013. In contrast, the percentage of firms with more than one female director increases steadily, from $23.8 \%$ in 1998 to $43.6 \%$ in 2013. Not surprisingly, the average CEO option moneyness plummets around the 2001-2002 dotcom bubble burst, and the 2007-2009 crisis given that 
CEOs are less likely to be overly optimistic during recessions. To ensure that our findings are not simply due to a recession effect, in Section 7.3 we show that the results are robust to excluding the two recession periods. In addition, the $2007-2009$ crisis provides an interesting setting to examine how firms with female directors perform during a crisis to shed. This analysis can be found in Section 6 .

\section{INSERT TABLE 1 ABOUT HERE}

Panel B presents the statistics across the 11 Fama-French industries (the twelfth industry, the financial industry, is excluded). There are notable differences across industries in terms of female board presence. Specifically, the percentage of firm-years with female directors ranges from a low of $56.2 \%$ in Business Equipment to a high of $92.4 \%$ in Utilities. The percentage of firm-years with more than one female director also varies across industries, ranging from $20.2 \%$ for Energy to $57.4 \%$ for Non-Durables. Finally, the industry with the lowest average CEO option moneyness is Utilities (0.401). In untabulated results, we find that the average male CEO holds options that are $68.6 \%$ in the money, which is significantly higher (at the $1 \%$ level) than the average moneyness of $45 \%$ for female CEOs. This difference is consistent with prior evidence that male executives exhibit relative overconfidence in their option holding and exercise decisions (Huang and Kisgen, 2013).

Table 2 contains summary statistics for the firm-years with male CEOs upon which most of our empirical analysis is based. The average fraction of female directors in firms with a male CEO is $10.4 \%$. The average firm has annual sales of 5619.7 million US dollars, leverage of $22.5 \%$, a stock return of $13.0 \%$, a return on assets of $14.3 \%$, and a Tobin's q of 1.9 . As to the governance and board characteristics, the fraction of independent directors is $72.6 \%$, board size is approximately 9 , and the $\mathrm{E}$ index has an average value of 2.6. These descriptive statistics are similar to those reported by previous studies (e.g. Adams and Ferreira, 2009). 
Moving onto the $\mathrm{CEO}$ characteristics, average $\mathrm{CEO}$ age and tenure are 56 years and 8 years, respectively. In addition, the average age at which a CEO becomes CEO for the first time is about 46 years. The mean and median of CEO ownership are $1.5 \%$ and $0.3 \%$. Further, the CEO is the firm's chair for $61.3 \%$ of all firm-year observations. The CEO holds professional qualifications for $8.4 \%$ and an MBA degree for $37.9 \%$ of all observations, respectively. Finally, the CEO has military experience for $6.6 \%$ of the firm-years and has attended an Ivy League university for $19.3 \%$ of the firm-years.

The rest of the table presents a comparison of firm-year observations with female directors and those without. There are significant differences between the two groups. In a nutshell, firms with female directors are associated with lower CEO option moneyness, greater sales revenue, higher leverage, fewer growth opportunities, higher accounting performance, but lower stock returns. In terms of the governance and CEO characteristics, firms with female directors have a greater fraction of independent directors, a larger board, a higher entrenchment index, a higher incidence of CEO duality, and a CEO with a better educational background but less experience.

\section{Empirical results}

\subsection{Baseline regressions}

Table 3 contains the regressions testing whether CEOs exhibit less overconfidence in their option holding and exercise behavior when there are women on the board. The base specifications in Panel A are ordinary least squares (OLS) panel regressions where the dependent variable is the CEO's option moneyness. Regressions (1) to (3) are based on the firm-years with male CEOs, and vary as to the control variables included. We start the analysis 
by regressing CEO option moneyness on the fraction of female directors as well as industry and year effects in regression (1). Regression (2) also includes the firm characteristics. In addition, regression (3) also controls for the governance and CEO characteristics.

In all the above specifications, the coefficient on Fraction of female directors is negative and statistically significant at the $1 \%$ level. In terms of economic significance, the coefficient in regression (3) indicates that a 10-percentage-point increase in the fraction of female directors is associated with a 6.24 percentage-point decrease in the male CEO's option moneyness. As the average male CEO option moneyness is $68.6 \%$, this represents a $9.1 \%$ reduction relative to the mean level. We also reran the regressions in Table 3 by including the square of Fraction of female directors, allowing for a non-linear relation between the fraction of female directors and the dependent variable. We did not find any evidence of such a nonlinear relation.

INSERT TABLE 3 ABOUT HERE

We also examine whether women on boards have any effect on the female CEO's option moneyness using the sample of firm-years with female CEOs in regression (4). We find no such evidence. Hence, the finding that the negative effect observed for male CEOs is not observed for female CEOs suggests that the relation between female representation on the board and the male CEO option moneyness likely reflects differences in gender. This confirms our hypothesis that female directors influence the behavior of male CEOs by making the latter less overconfident about their firm's prospects. In what follows, we focus on the male CEO sample.

In Panel $\mathrm{B}$, we estimate several other specifications for robustness. We first estimate a firm fixed effects regression (regression (1)) to address the potential joint determination problem whereby an unobserved time-invariant firm characteristic simultaneously determines 
CEO option moneyness and Fraction of female directors. The firm fixed effects regressions take into account the effects of within-firm changes on CEO option moneyness. The results suggest that firm-specific unobservables cannot explain the relation between CEO option moneyness and Fraction of female directors. We verify the robustness of our results using a Fama-and-MacBeth regression (regression (2)) with Newey-West standard errors.

At the CEO-firm level, we find somewhat mixed evidence. First, the coefficient on the female director variable remains negative, but becomes statistically insignificant, when we estimate a CEO-firm fixed effects specification (regression (3)). One possible explanation is that using more granular fixed effects significantly reduces the within variation available for estimation. In support of this view, we observe significantly lower within CEO-firm variation than within firm variation. The number of changes in female board representation decreases from 2.383 in the average firm to 1.183 in the average CEO-firm, i.e. a $50.4 \%$ reduction. The lack of within CEO-firm variation would then work against finding a significant effect of female board representation on CEO overconfidence in CEO-firm fixed effects regressions (Zhou, 2001). We therefore restrict our sample to CEO-firm pairs with more than one change in female board representation to have a similar level of within variation to that of the firm fixed effects specifications. We then repeat the main analysis using the CEO-firm fixed effects regression on this restricted sample and find a negative and statistically significant effect of female board representation on CEO overconfidence (regression (4)). While adding confidence to the validity of our findings, we recognize that these results should be interpreted with caution because the sample restriction approach might have introduced selection bias that we are not able to eliminate in our setting. Third, we will show further evidence at the CEO-firm level in Section 4.2 .3 by examining changes in CEO option moneyness around director appointments under the same CEO. 
Regressions (5) and (6) are two different logit models whose dependent variable is an indicator variable set to one if the CEO has estimated option moneyness greater than $100 \%$ and $67 \%$, respectively, and zero otherwise. These binary measures identify CEOs with relatively high optimism. The two cutoffs of $100 \%$ and $67 \%$ are suggested by Campbell et al. (2011), Malmendier and Tate (2005), and Malmendier and Tate (2008). In all the above specifications, the coefficient on Fraction offemale directors is negative and statistically significant at the $1 \%$ level, confirming the negative effect of female board representation on the male CEO's option moneyness.

\subsection{Identification}

While the results so far are robust and consistent with the hypothesis, the observed relation between Fraction of female directors and CEO option moneyness could be spurious due to the endogenous nature of board composition (Wintoki et al., 2012). For instance, there could be some unobserved firm and CEO characteristics affecting both the selection of female directors and the CEO's option exercise decisions. Alternatively, overconfident and powerful CEOs may have influence over the board selection process and in turn board gender composition.

To address these concerns, we employ three approaches. We first conduct propensity score matching whereby firm-years with female directors are matched with those without, based on observable characteristics. We also employ an instrumental variable approach to adjust for the potential endogeneity of board composition. Finally, we employ a difference-indifferences (DID) matching estimator that exploits changes in female board representation resulting from female director appointments to identify whether women on the board affect the male CEO's behavior. Overall, the tests confirm our baseline results and show that the data is inconsistent with several particular concerns. While these observations are reassuring, we are 
careful to recognize that our analyses do not allow us to completely rule out alternative explanations in general.

\subsubsection{Propensity score matching estimates}

To identify a control sample of firm-year observations without female directors that exhibit no significant differences in observable characteristics compared to those with female directors, we first estimate the probability that a firm hires female directors using a logit model, i.e., regression (1) of Panel A in Table 4, which includes the same controls as regression (3) of Panel A in Table 3. This specification captures a significant amount of variation in the presence of female directors, as indicated by a pseudo $\mathrm{R}^{2}$ of $29.4 \%$ and a $p$-value from the $\chi^{2}$ test (not tabulated) of the overall fit of the model well below 0.001. The results suggest that firms with female directors are larger and have larger and more independent boards, consistent with Adams and Ferreira (2009).

We then construct a treatment group and a control group of observations using the nearest-neighbor method based on the predicted probabilities, or propensity scores, from regression (1) of Panel A. Specifically, each firm-year with female directors (the treatment group) is matched with the firm-year without female directors (the control group) with the closest propensity score. If a firm-year in the control group is matched with more than one firm-year in the treatment group, we retain only the pair for which the difference in propensity scores is the smallest. To ensure that observations in the treatment and control groups are sufficiently indistinguishable, we further require that the maximum difference (i.e., the caliper) between the propensity score of each firm-year with female directors and that of its matched peer does not exceed 0.01 in absolute value. We obtain 2,250 unique pairs of matched observations. 
We conduct two diagnostic tests to verify that observations in the treatment and control groups are truly indistinguishable in terms of observable characteristics. The first test consists of re-estimating the logit model (not tabulated) underlying the propensity score using the matched sample (see regression (2) of Panel A). All of the coefficient estimates are statistically insignificant, indicating that there are no distinguishable trends between the two groups. Further, the pseudo $\mathrm{R}^{2}$ drops substantially from $29.4 \%$ in the pre-match model to only $0.3 \%$ in the post-match model. The $\chi^{2}$ test also fails to reject the null hypothesis that all coefficient estimates equal zero.

\section{INSERT TABLE 4 ABOUT HERE}

The second test consists of examining the difference in means for each observable characteristic between the treatment and matched control groups. The results, reported in Panel B of Table 4, show that none of the differences is statistically significant. Overall, the diagnostic test results suggest that the propensity score matching removes observable differences other than the difference in board gender composition. Thus, it increases the likelihood that any difference in CEO option moneyness between the two groups is due to the presence of female directors on the board. Finally, Panel $\mathrm{C}$ of Table 4 reports the propensity score matching estimates. The results suggest that, if a director is female, the male CEO's option moneyness decreases by 8.1 percentage points on average, which amounts to an $11.8 \%$ reduction relative to the mean level. This effect is significant at the $1 \%$ level. Thus, potential matching between female directors and firms/CEOs does not drive our findings to the extent that the omitted factors are observable.

In untabulated tests, we examine the robustness of the results to alternative matching criteria and we confirm that our findings are essentially unchanged when we conduct the nearest-neighbor matching based on propensity scores (i) within the same Fama-French 49 
industry and year; (ii) within the same Fama-French 49 industry, year, and MBA category; and (iii) within the same Fama-French 49 industry, year, and Ivy League category. Finally, we reestimate the baseline models using the matched samples. The results are qualitatively similar.

\subsubsection{Instrumental variable estimates}

To jointly address our concerns of potential unobserved heterogeneity and reverse causality, we use the instrumental variables approach to extract the exogenous component of female board representation. The latter is then used to explain the male CEO's option moneyness. As sources of exogenous variation, we use two instrumental variables that capture a firm's likelihood of appointing female directors, one at the firm level and the other at the state level. Both are uncorrelated with $C E O$ option moneyness, except through variables we control for.

The first instrument is the fraction of a firm's male directors who sit on other boards with at least one female director, which has also been used by Adams and Ferreira (2009) and Levi et al. (2014). The rationale behind this instrument is that the more connected a firm's male directors are to women, the more female directors should be observed and appointed (Adams and Ferreira, 2009). Therefore, we expect this instrumental variable to be positively correlated with the fraction of female directors. The second instrument is the female-to-male population ratio calculated as the female population divided by the male population in the state where the firm is headquartered. Firms in states where the female-to-male population ratio is higher are more likely to find qualified female candidates for their board of directors, ceteris paribus, given the potentially broader talent pools. Therefore, we expect that, the greater the female-tomale population ratio, the greater the representation of women on boards will be. Meanwhile, it is reasonable to argue that a state's female-to-male population ratio is not directly correlated with CEO option moneyness. 
The first column of Table 5 (regression (1)) contains the results of the first-stage regression where the dependent variable is the fraction of female directors. Consistent with our prediction, the coefficient estimates for the two instruments are positive and significant at the $1 \%$ level. We conduct three additional tests to verify that our instruments are not weak. First, we test the joint significance of the two instruments and find that the value of the F-test is relatively large (9.120) and highly significant ( $p$-value $=0.000)$. Second, the $p$-value of the Cragg-Donald's Wald $F$ weak-instrument test statistic is close to zero, rejecting the null hypothesis that the instruments are weak (Cragg and Donald, 1993; Stock and Yogo, 2005). ${ }^{3}$ Third, the $p$-value for Hansen's $J$ over-identification test is large $(0.170)$, suggesting that the two instruments are valid, i.e., uncorrelated with the error term (Hansen, 1982).

\section{INSERT TABLE 5 ABOUT HERE}

The second column (regression (2)) contains the second-stage regression results where the dependent variable is the male CEO's option moneyness. The main variable of interest is the predicted value of the fraction of female directors. The coefficient on Fraction of female directors is negative and significant at the $1 \%$ level. Male CEOs at firms with lower fractions of female directors tend to hold options that are deeper in the money, after endogeneity is taken care of, confirming the causal relationship between female board representation and less overconfidence in the male CEO's option exercise decisions.

A potential concern is that the Fraction male linked to female instrument might capture the connectedness of the board and bias the results. To address this concern, we follow Adams and Ferreira (2009) in controlling for more direct measures of board connectedness

\footnotetext{
${ }^{3}$ The Stock and Yogo (2005) critical value with one endogenous regressor and two instrumental variables based on 2SLS size is 19.93. For all the regressions, the Cragg Donald Wald F-statistic is much larger than 19.93. Therefore, we reject the null hypothesis that the instruments are weak.
} 
(regressions (3) to (6)): the total number of external board seats held by directors and male directors, respectively. Our results are robust to the inclusion of these additional controls.

\subsubsection{Changes in CEO option moneyness around director appointments}

We also employ an identification strategy of difference-in-differences (DID) around female director appointments, which do not coincide with a CEO change, to identify the effect of women on boards. The DID analysis compares the outcomes for two similar groups with and without the treatment but that would otherwise be subject to similar influence from the trending variables. Therefore, if any trends in outcomes for the two groups prior to treatment are the same (i.e., the parallel trends assumption), then the impact of the treatment should be reflected in the difference between the changes for the two groups (Roberts and Whited, 2013).

This analysis is based on the firm-years one year before and one year after a director appointment. To be included in the treatment group, the firm must appoint only one female director to replace a departing male director in the year of the appointment and the departing male director must be older than 60 to ensure that director turnover is more likely due to retirement than to corporate strategic changes or bad director performance. As stated above, to eliminate the possible confounding effects of CEO changes we exclude firms that experience CEO turnover during the period. Applying these criteria results in 60 female director appointments for the treatment group. For the control group, we identify 174 observations where a departing male director aged above 60 is replaced with one newly appointed male director.

We then match treatment and control observations using propensity score matching to help satisfy the parallel trends assumption and ensure that the results are not driven by differences in CEO, firm and/or industry characteristics. The matching procedure is analogous 
to that described in section 4.2. We end up with 56 unique pairs of matched firms. Based on this matched sample, we estimate the following regression.

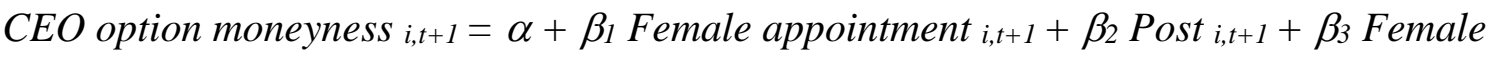

$$
\text { appointment }_{i, t+1} \times \text { Post }_{i, t+1}+\gamma Z_{i, t}+\text { Industry }_{i}+\text { Year }_{t}+\varepsilon_{i, t}
$$

where Post is an indicator variable stating whether the year is after the director appointment. Female appointment is an indicator variable stating whether the firm is in the treatment group.

The results are reported in the first column (regression (1)) of Table 6, which includes the same firm, governance and CEO controls as in regression (3) of Panel A in Table 3. The coefficient on Female appointment $\times$ Post is negative and significant at the $5 \%$ level, indicating that, after female director appointments, male CEOs are less likely to exhibit overconfidence in their personal portfolio decisions than after male director appointments. The estimated effect is also economically meaningful. On average, male CEOs tend to hold options that are 28.2 percentage points lower in the money (or $41.1 \%$ lower relative to the mean level) for the year after the female director appointment than they do after the male director appointment.

\section{INSERT TABLE 6 ABOUT HERE}

If it is harder for women to get on the board than it is for men, then the potential selection and resulting quality differences between female and male directors could alter the interpretation of the results. For example, it could be the case that those females that break through the glass ceiling are much better than their male counterparts. We take two steps to mitigate the concern that our findings are driven by differences in director quality and not gender. First, in regression (2) we include controls to capture several observable dimensions of director quality: Dummy_MBA replaces non-MBA (Dummy_Non-MBA replaces MBA) is an indicator variable stating whether the departing director without (with) an MBA degree is 
replaced with a new director with (without) an MBA degree; Dummy_Non-Ivy replaces Ivy (Dummy_Ivy replaces non-Ivy) is an indicator variable stating whether the departing director who attended (did not attend) an Ivy-League university is replaced with a new director who did not (did); Dummy_Qualif. replaces non-Qualif. (Dummy_Non-Qualif. replaces Qualif.) is an indicator variable stating whether a departing director without (with) professional qualifications is replaced with a new director with (without) professional qualifications. The results show that controlling for the education and qualification variables does not have a large impact on the magnitude of the coefficient on the interaction term. Second, in regression (3) we use director-pair fixed effects (i.e., fixed effects for each pair of departing male director and his replacement new director) to eliminate the impact of any unobserved time-invariant director characteristics on CEO option moneyness. The coefficient on the interaction term remains negative and significant at the 5\% level. Thus, we conclude that the effect of female board representation on CEO overconfidence is not due to selection.

To rule out alternative explanations pertaining to reverse causality, we examine the dynamics of the female board representation effect in regressions (4) and (5). The sample for this additional analysis includes the firm-years up to two years before and up to two years after a director appointment. Specifically, we create dummy variables indicating the first year and second year before the appointment (Post -1 and Post -2 ), the first year after the appointment $($ Post +1$)$, and two years after the appointment $($ Post +2$)$, and replace Female appointment $\times$ Post with the four interaction terms between Female appointment and these dummies. If our results are affected by reverse causation, the likelihood of appointing a female director might already be correlated with CEO option moneyness before the appointment, and thus we should observe a negative and significant coefficient on Female appointment $\times$ Post -2 and/or Female appointment $\times$ Post -1 . However, the results indicate that, in both the OLS and director-pair fixed-effects specifications, it is only after the appointment that the negative effect on $C E O$ 
option moneyness becomes large and significant. Hence, the estimated female board representation effect does not reflect reverse causation or pre-existing trends.

\subsection{Female board representation and CEO overconfidence: Additional evidence from} exercised options

The CEO option moneyness variable used in the above analyses measures the average moneyness of all exercisable options held by the CEO, which could vary (i) when the CEO exercises some existing options, and (ii) when new packages of options become vested and exercisable. The former source of variation captures differences in the CEO's exercise behavior. The latter, however, is less likely to reflect CEO behavior and beliefs since the CEO has little control over it. As an alternative, we isolate the observations relating to option exercises and examine the relation between the characteristics of exercised options and female board representation. For each option exercise in the sample, we study the following two characteristics: Value ratio, i.e. the ratio of the intrinsic value to the strike price of the option, where the intrinsic value is calculated as the stock price at exercise minus the strike price; and Time to expiration, i.e. the remaining number of years until the option expiration at exercise. This data is then aggregated for each CEO on an annual basis, using a simple average for the number of options exercised. The option exercise data is from the Thomson Reuters Insider Filings database. Sen and Tumarkin (2015) show that optimistic CEOs exercise options closer to expiration and at higher stock prices than non-optimistic CEOs. Untabulated results suggest that female board representation is associated with less optimistic option exercise choices characterized by more time remaining until expiration and lower value ratios at exercise. 


\section{Does female board representation matter across all industries?}

Extant research shows that too much managerial overconfidence is detrimental to the firm because it leads CEOs to form overly optimistic views about investment opportunities, resulting in overinvestment, a heightened sensitivity of investment to cash flows, and suboptimal acquisition decisions (Malmendier and Tate, 2005; Malmendier and Tate, 2008; Malmendier et al., 2011; Banerjee et al., 2015). Hence, it is possible that female board representation, by mitigating the CEO's optimistic bias, reduces overinvestment and the sensitivity of investment to cash flows, as well as improving acquisition decisions, and ultimately firm performance. Then it follows that board gender composition may be particularly important in industries where CEOs are more likely to develop overconfidence and the moderating effects of female board representation on corporate investment decisions should be more prominent in these industries.

The propensity of CEOs to hold biased beliefs may vary across industries, as differences in industry-wide practices (e.g., work attitudes, motivation techniques, and managerial practices) and growth prospects may significantly influence individual behavior (Rasmussen and Rauner, 1996). Further, field studies imply that overconfidence is more likely to occur in industries where the decision-making environment is non-repetitive and ambiguous, resulting in lack of prior similar actions to help calibrate judgment (Simon and Houghton, 2003). Consistent with these conjectures, we find that the dispersion of overconfidence among CEOs varies considerably across industries during the sample period and that the industries with the highest average CEO option moneyness are pharmaceuticals, computer software, coal, and construction.

To capture the cross-industry differences in the prevalence of overconfidence, we construct a variable named High industry OC (overconfidence) representation. It is an indicator variable that equals one if the fraction of overconfident CEOs for an industry in that year is 
greater than the sample median across all industries, and zero otherwise, with overconfident CEOs being those who hold stock options that are more than $67 \%$ in the money. We find evidence that the effects of female board representation on corporate investment decisions are more prominent in industries with a high prevalence of overconfident beliefs.

In what follows, we investigate whether this differential effect of female board representation across industries remains when we focus on specific corporate decisions. Table 7 presents the regression results where the dependent variable is capital expenditures scaled by beginning-of-year net property, plant and equipment. For each specification, we estimate the regression using two alternative econometric techniques: OLS and firm fixed effects. First, for regressions (1) to (3) based on the whole sample, the coefficient on Fraction offemale directors is insignificant, but the coefficient on the interaction of the former with the industry overconfidence prevalence variable is negative and significant at the $10 \%$ level or better. This suggests that female board representation reduces investment in industries with high overconfidence prevalence. There is no such effect in industries with low overconfidence prevalence. In a similar vein, in unreported tables we find that female board representation also helps moderate assets growth (measured by the growth in total assets and growth in property, plant and equipment) in industries with high overconfidence prevalence, but not in those with low overconfidence prevalence.

\section{INSERT TABLE 7 ABOUT HERE}

Malmendier and Tate (2005) find that managerial overconfidence is associated with a heightened sensitivity of corporate investment to cash flows, i.e., overconfident CEOs overinvest when the firm has abundant internal funds, but investment is curtailed when the firm requires external financing. By moderating managerial overconfidence, female board representation is likely to reduce the investment sensitivity to cash flows. 
To test our conjecture, we include Cash flow and its interaction with Fraction of female directors in regressions (4) to (9). The first three regressions are based on the subsample with above median industry $O C$ representation and the latter three regressions are based on the subsample with below median industry OC representation. As per our expectations, we find that the coefficient on the interaction is negative and statistically significant only in the high industry overconfidence prevalence subsample.

Malmendier and Tate (2008) argue that CEOs with overly optimistic beliefs tend to overestimate their ability to generate returns, overpay for target firms, and make valuedestroying acquisitions. Thus, we expect female board representation to have a positive effect on shareholder gains from acquisitions by attenuating managerial overconfidence about acquisition activities, especially in industries with high overconfidence prevalence. This is tested in Table $8 .{ }^{4}$ We start by estimating an OLS model (regression (1)) where the dependent variable is the acquirer's cumulative abnormal returns (CAR) from five days before the acquisition announcement to five days after. The coefficient on Fraction of female directors is insignificant, whereas the coefficient on the interaction is positive and significant at the $5 \%$ level, suggesting that female board representation makes a positive contribution to cumulative abnormal returns in industries with high overconfidence prevalence, but not in those with low overconfidence prevalence.

\footnotetext{
${ }^{4}$ The acquisition sample starts with all acquisition announcements listed in the Securities Data Company (SDC) database, which we then merge with accounting data, stock return and CEO characteristics data. Following previous studies (e.g., Malmendier and Tate, 2008; Netter et al., 2011), we impose the following restrictions on our sample: (i) the deal status is "completed"; (ii) the acquirer is a US publicly listed firm, and the target is a US public or private firm, and neither is in the financial services industries; (iii) the acquiring firm obtains at least $50 \%$ of the target shares; (iv) the percentage of stocks held by the acquiring firm six months prior to the announcement must be below $50 \%$; (v) deal value is greater than $5 \%$ of the acquirer value; (vi) the deal type is "disclosed and undisclosed (deal value) deals"; and (vii) the deal announcement occurs between 1998 and 2013.
} 


\section{INSERT TABLE 8 ABOUT HERE}

Regression (2) is the second-step regression from the Heckman two-step method to address the potential self-selection bias in deal-initiation decisions. The first step involves estimating a selection equation for the deal-initiation decision. Following Masulis and Simsir (2015), we use Prior industry merger intensity as the identifying instrument in the first-step equation. It is calculated as the total number of merger deals in the industry (based on the FamaFrench 49-industry classification) within the past two years divided by the total number of mergers across all industries over the same period. On the one hand, CEO deal initiation decisions are likely to be positively related to the frequency of prior deals in their industry. On the other hand, there is no clear economic rationale for Prior industry merger intensity to affect the outcome variable directly. In the second step, we estimate the same model as regression (1) of Table 6, augmented by the estimated inverse Mills ratio from the first step. Our results are robust to this alternative approach.

Finally, we examine whether the above moderating effects of female board representation contribute to firm performance and value. Table 9 shows that female board representation influences neither firm value, measured by Tobin's $q$, nor firm performance, measured by the return on equity $(R O E)$ and return on assets $(R O A)$, in low overconfidence-prevalence industries, as indicated by the insignificant coefficient on Fraction of female directors. However, the coefficient on the interaction term between Fraction offemale directors and High industry $O C$ representation is positive and significant (with one exception), suggesting that female board representation helps alleviate investment distortions associated with managerial overconfidence and improve firm value and performance, especially in industries with high overconfidence prevalence. 


\section{Female board representation and corporate performance during the 2007-2009 crisis}

The recent crisis has been described as the worst crisis over the past decades. Ho et al. (2016) find a link between managerial overconfidence and poor performance during the crisis. They argue that overconfident CEOs tend to overestimate the probability of a positive state, underestimate the downside risk of a project, and pursue aggressive strategies that ex post make their firms more vulnerable during a crisis. Thus, if female directors are more likely to caution against an overly optimistic assessment of investment prospects during an economic upswing, then (i) the subsequent crisis should represent less of a shock to CEOs with female directors on their boards; and (ii) firms with female directors should experience less of a reduction in operating and stock performance.

Mian and Sufi (2014) show that regions that suffered larger drops in house prices were more severely affected by the crisis, resulting in a larger reduction in consumption and employment. Accordingly, we exploit state differences in the house price collapse to capture the cross-sectional variation in the severity of the crisis. We then investigate whether female board representation attenuates the effect of the crisis on the change in the variable of interest. Specifically, we estimate the following regression:

$$
\begin{aligned}
\Delta y_{i, s}=\alpha & +\beta_{1} \text { Fraction of female directors } i_{, s}+\beta_{2} \text { Ist }_{\text {Qtile House price shock }} \\
& +\beta_{3} \text { 1st Qtile House price shock }{ }_{s} \times \text { Fraction of female directors } i, s \\
& +\beta_{4} \text { 4th Qtile House price shock }{ }_{s}+\beta_{5} \text { 4th Qtile House price shock }{ }_{s} \\
& \times \text { Fraction of female directors } i, s+\gamma Z_{i, s}+\text { Industry }_{i, s}+\varepsilon_{i, s}
\end{aligned}
$$

where index $i$ refers to the firm and index $s$ refers to the state where the firm has its headquarters. $\Delta y$ is the change from 2007 to 2009 in the variable of interest, including CEO option moneyness, 
Tobin's q, ROA, and ROE. We classify House price shock into quartiles to allow for the potential nonlinear type of relation between the severity of the house price collapse and the variables of interest. 1st Qtile House price shock and 4th Qtile House price shock are indicator variables for the first (least severe) quartile and the fourth (most severe) quartile of House price shock, where House price shock is the percentage drop in the Zillow Home Value Index (ZHVI) $)^{5}$ from December 2006 to December 2009 in the state of the company's headquarters. Fraction of female directors is defined as previously. As in previous regressions, we control for the same firm, governance, and CEO characteristics, all measured in 2006. Our timings are consistent with recent studies of the recession (Mian and Sufi, 2014).

Several important observations can be made about Table 10. First, for the house price shock quartiles, only the coefficient on the 4th quartile tends to be significant, suggesting that the relation is asymmetric. Second, in regression (1) where the dependent variable is the change in CEO option moneyness, the coefficient on the interaction term 4th Qtile House price shock $\times$ Fraction of female directors is positive and significant at the $5 \%$ level, weakening the negative impact of 4th Qtile House price shock on the CEO's option moneyness. Being cautioned against overconfident views about the firm's prospects in the noncrisis years, CEOs of firms with female board representation appear to be less shocked by and adjust their personal portfolios less substantially in response to the subsequent crisis. Third, in regressions (2) to (4) where the dependent variable is the change in firm performance/value, again the coefficient on the interaction term 4th Qtile House price shock $\times$ Fraction of female directors is generally positive and significant, offsetting the negative baseline effect of 4th Qtile House price shock.

\footnotetext{
${ }^{5}$ The house value index data is obtained from Zillow (http://www.zillow.com/research/data/). Zillow provides estimates of the price of more than 110 million individual houses in the US. These house-level valuations are then aggregated into the Zillow Home Value Index (ZHVI). We find that, on average, the ZHVI dropped by $10.5 \%$ from December 2006 to December 2009.
} 
To sum up, all the above findings suggest that CEOs with gender-diverse boards adopt less aggressive strategies that make their firms less vulnerable to the crisis.

\section{INSERT TABLE 10 ABOUT HERE}

\section{Further discussion and robustness tests}

One possible concern is that the option-based measure may capture the CEO's willingness to take risk (Kamiya et al., 2019), suggesting an alternative explanation whereby male CEOs become less risk tolerant rather than less overconfident in the presence of female directors. A key distinction between an overconfidence story and a risk tolerance story is in regard to how the option-based measure affects investment-cash flow sensitivity. The overconfidence hypothesis predicts a positive effect of the option-based measure on investment-cash flow sensitivity (Malmendier and Tate, 2005). This is because overconfident CEOs tend to overinvest when they have abundant internal funds as they overestimate the returns from their investment projects. When firms require external financing, however, they curtail investment because they view external funds as unduly costly. On the other hand, if holding deep-in-themoney options reflects higher risk tolerance, high option moneyness should be associated with lower investment-cash flow sensitivity since less risk-averse managers should be more willing to leverage up the firm, if necessary, to finance investment projects (Malmendier and Tate, 2008; Hirshleifer et al., 2012). We find a positive relation between the option-based measure and investment-cash flow sensitivity in our sample, which is contrary to the risk tolerance interpretation. This finding is consistent with that of Malmendier and Tate (2005).

To further rule out alternative explanations related to risk taking, we re-estimate the effect of female board representation on CEO option moneyness after including additional controls. Volatility is the annualized standard deviation of the firm's weekly stock return over the past year. $\operatorname{Ln}(1+$ Delta $)$ is the natural logarithm of one plus CEO delta, where delta is defined as 
the change in the value of the CEO's wealth due to a $1 \%$ increase in the firm's stock price. $\operatorname{Ln}(1+V e g a)$ is the natural logarithm of one plus CEO vega, where vega is defined as the change in the value of the CEO's wealth due to a 0.01 increase in the annualized standard deviation of the firm's stock return. ${ }^{6}$ The results are robust to controlling for these variables, suggesting that differences in managerial risk taking cannot explain our findings.

Another possible concern is that the results are driven by a few very vocal female directors, given the smaller pool of female directors compared to that of male directors. To address this concern, we repeat the baseline analysis after excluding firm-years corresponding to at least one female director having more than three, four, five, and six directorships, respectively. Still, we find that the coefficient on the female director variable remains positive and statistically significant in all specifications.

Further, we examine whether the negative effect of female board representation on CEO overconfidence becomes stronger with the number of female directors and/or their roles on the board. Not surprisingly, we find that the negative effect is more prominent when there is more than one female director on the board and when at least one female director sits on board committees or serves as the CFO. These results, along with other results in the paper, appear to suggest that the increased presence of women on boards is more than window dressing.

Finally, we take additional steps to ensure the robustness of our main findings. We confirm that our main findings continue to hold when (i) two alternative measures of overconfidence including Net buyer and Share retainer are used; ${ }^{7}$ (ii) firm-years with CEO

\footnotetext{
${ }^{6}$ The data on managerial compensation incentives is from Coles et al. (2006) and can be obtained at http: //sites.temple.edu/lnaveen/data/.

${ }^{7}$ We construct two alternative measures of overconfidence based on the CEO's stock transactions: (i) Net buyer is an indicator variable that equals one if the CEO is a net buyer of company stock in that year, and zero otherwise;
} 
turnover are excluded to eliminate potential, confounding effects; (iii) the two crisis periods, the 2001-2002 dotcom bubble burst and the 2007-2009 crisis, are excluded; (iv) alternative clustering and alternative industry classifications are used (i.e., clustering by year, industry, or double clustering by firm and year, two-digit SIC industry dummies, three-digit NAICS industry dummies, or industry-year dummies).

\section{Conclusion}

We find that male CEOs at firms with female directors are less likely to hold options deep in the money, suggesting that female board representation moderates the CEO's overly optimistic beliefs about the firm's growth prospects. Further, we find that female board representation matters more in some industries than in others. More specifically, female board representation is associated with lower investment, reduced investment sensitivity to cash flows, less aggressive assets growth, better acquisition decisions, and ultimately improved firm performance in industries with high overconfidence prevalence, but not in those with low overconfidence prevalence, consistent with the view that female board representation affects firm outcomes through reducing the optimistic bias of male CEOs. Finally, we show that female board representation explains part of the cross-sectional heterogeneity in firm performance during the 2007-2009 crisis. The results suggest that firms with female directors experience a smaller drop in operating and stock performance during the crisis. All these findings highlight the importance of female board representation and provide evidence of female directors mitigating the CEO's overconfidence.

A meaningful extension to the paper involves identifying the channel(s) whereby female directors manage to reduce male CEO overconfidence when making corporate decisions. One

and (ii) Share retainer is an indicator variable that equals one if the fraction of shares retained from option exercise during a year exceeds $1 \%$, and zero otherwise. 
possibility is that female directors change boardroom dynamics, e.g. via improving the quality and/or intensity of discussions around complex decision problems. Heterogeneity of preferences and viewpoints between female and male directors would then result in moderated and less skewed beliefs about the firm's prospects. Hence, the addition of even a single female director to an all-male board (and thus breaking the "old boys" atmosphere) is likely to be impactful. Drawn from the literature on minority influence, merely being exposed to a differing, minority viewpoint influences the holders of the majority viewpoint by making them more likely to engage in divergent thinking, leading to more thorough and comprehensive decisionmaking processes (Peterson and Nemeth, 1996).

However, to test the validity of this argument one would require access to board meetings, or to the very least access to detailed minutes of board meetings, which are not accessible to us. Using detailed minutes of board and board-committee meetings for 11 Israeli companies with a significant equity stake by the government, Schwartz-Ziv (2017) finds some evidence that female directors are more active at board-committee meetings than male directors. This finding is consistent with our conjecture, but only to the extent that the boardroom dynamics of Israeli government-controlled companies are similar to those of American firms. Future research that specifies the working of boardroom dynamics should shed more light on both the role of women in the boardroom, and corporate policy implications of mitigating managerial overconfidence. 


\section{REFERENCES}

Adams, R.B., Ferreira, D., 2009. Women in the boardroom and their impact on governance and performance. Journal of Financial Economics 94, 291-309.

Agarwal, S., Driscoll, J., Gabaix, X., Laibson, D., 2009. The age of reason: Financial decisions over the life cycle and implications for regulation. Brookings Papers on Economic Activity 2, $51-117$.

Ahern, K.R., Dittmar, A.K., 2012. The changing of the boards: The impact on firm valuation of mandated female board representation. Quarterly Journal of Economics 127, 137-197.

Banerjee, S., Humphery-Jenner, M., Nanda, V., 2015. Restraining overconfident CEOs through improved governance: Evidence from the Sarbanes-Oxley Act. Review of Financial Studies 28, $2812-2858$.

Bebchuk, L., Cohen, A., Ferrell, A., 2009. What matters in corporate governance? Review of Financial Studies 22, 783-827.

Beck, T., Behr, P., Madestam, A., 2018. Sex and credit: Do gender interactions matter for credit market outcomes? Journal of Banking and Finance 87, 380-396.

Bellucci, A., Borisov, A., Zazzaro, A., 2010. Does gender matter in bank-firm relationships? Evidence from small business lending. Journal of Banking and Finance 34, 2968-2984.

Bennouri, M., Chtioui, T., Nagati, H., Nekhili, M., Female board directorship and firm performance: What really matters? Journal of Banking and Finance 88, 267-291.

Bertrand, M., Schoar, A., 2003. Managing with style: The effect of managers on firm policies. Quarterly Journal of Economics 118, 1169-1208.

Bordalo, P., Gennaioli, N., Shleifer, A., 2012. Salience theory of choice under risk. Quarterly Journal of Economics 127, 1243-1285.

Campbell, K., Minguez-Vera, A., 2008. Gender diversity in the boardroom and firm financial performance. Journal Business Ethics 83, 435-451. 
Campbell, T.C., Gallmeyer, M., Johnson, S.A., Rutherford, J., Stanley, B.W., 2011. CEO optimism and forced turnover. Journal of Financial Economics 101, 695-712.

Carter, S.M., 2006. The interaction of top management group, stakeholder, and situational factors on certain corporate reputation management activities. Journal of Management Studies $43,1145-1176$.

Chen, G., Liu, C., Tjosvold, D., 2005. Conflict management for effective top management teams and innovation in China. Journal of Management Studies 42, 277-300.

Chen, G.L., Crossland, C., Huang, S., 2016. Female board representation and corporate acquisition intensity. Strategic Management Journal 37, 303-313.

Coles, J.L., Daniel, N.D., Naveen, L., 2006. Managerial incentives and risk taking. Journal of Financial Economics 79, 431-468.

Croson, R., Gneezy, U., 2009. Gender differences in preferences. Journal of Economic Literature 47, 448-474.

Edmans, A., Gabaix, X., 2011. The Effect of Risk on the CEO Market. Review of Financial Studies 24, 2822-2863.

Elder, G., Clipp, E., 1989. Combat experience and emotional health: Impairment and resilience in later life. Journal of Personality 57, 311-341.

Farrell, K.A., Hersch, P.L., 2005. Additions to corporate boards: The effect of gender. Journal of Corporate Finance 11, 85-106.

Goel, A.M., Thakor, A.V., 2008. Overconfidence, CEO selection, and corporate governance. Journal of Finance 63, 2737-2784.

Goergen, M., Limbach, P., Scholz, M., 2015. Mind the gap: The age dissimilarity between the chair and the CEO. Journal of Corporate Finance 35, 136-158.

Graham, J.R., Harvey, C.R., Puri, M., 2013.Managerial attitude and corporate actions. Journal of Financial Economics 109,103-121. 
Gul, F.A., Srinidhi, B., Ng, A.C., 2011. Does board gender diversity improve the informativeness of stock prices? Journal of Accounting and Economics 51, 314-338.

Hall, B.J., Murphy, K.J., 2002. Stock options for undiversified executives. Journal of Accounting and Economics 33, 3-42.

Heugens, P.P.M.A.R., Van Riel, C.B.M., Van Den Bosch, F.A.J., 2004. Reputation management capabilities as decision rules. Journal of Management Studies 41, 1349-1377.

Hilary, G., Menzly, L., 2006. Does past success lead analysts to become overconfident? Management Science 52, 489-500.

Hill, C.W.L., Jones, T.M., 1992. Stakeholder-agency theory. Journal of Management Studies 29, 131-154.

Hillman, A, Cannella, A.A. Jr., Harris, I.C., 2002. Women and racial minorities in the boardroom: How do directors differ? Journal of Management 28, 747-763.

Hirshleifer, D., Low, A., Teoh, S.H., 2012. Are overconfident CEOs better innovators? Journal of Finance 67, 1457-1498.

Ho, P.H., Huang, C.W., Lin, C.Y., Yen, J.F., 2016. CEO overconfidence and financial crisis: Evidence from bank lending and leverage. Journal of Financial Economics, forthcoming. Huang, J.K., Kisgen, D.J., 2013. Gender and corporate finance: Are male executives overconfident relative to female executives? Journal of Financial Economics 108, 822-839. Kahneman, D., 2011. Thinking, fast and slow. Farrar, Strauss, Giroux, New York, NY. Kamiya, S., Kim, Y.H., Park, S., 2019. The face of risk: CEO facial masculinity and firm risk. European Financial Management 25, 239-270.

Kolasinski, A.C., Li, X., 2013. Can strong boards and trading their own firm's stock help CEOs make better decisions? Evidence from acquisitions by overconfident CEOs. Journal of Financial and Quantitative Analysis 48, 1173-1206. 
Levi, M., Li, K., Zhang, F., 2014. Director gender and mergers and acquisitions. Journal of Corporate Finance 28, 185-200.

Lins, K.V., Servaes, H., Tamayo, A., 2017. Social capital, trust, and firm performance: The value of corporate social responsibility during the financial crisis. Journal of Finance, forthcoming.

Liu, Y., Wei, Z.B., Xie, F.X., 2014. Do women directors improve firm performance in China? Journal of Corporate Finance 28, 169-184.

Malmendier, U., Tate, G., 2005. CEO optimism and corporate investment. Journal of Finance 60, 2661-2700.

Malmendier, U., Tate, G., 2008. Who makes acquisitions? CEO overconfidence and the market's reaction. Journal of Financial Economics 89, 20-43.

Malmendier, U., Tate, G., Yan, J., 2011. Overconfidence and early-life experience: The effect of managerial traits on corporate financial policies. Journal of Finance 66, 1687-1733.

Masulis, R.W., Simsir, S.A., 2015. Deal initiation in mergers and acquisitions. Working Paper. Matsa, D.A., Miller, A.R., 2013. A female style in corporate leadership? Evidence from quotas. American Economic Journal: Applied Economics 5, 136-169.

Mian, A., Sufi, A., 2014. What explains the 2007-2009 drop in employment? Econometrica 82, 2197-2223.

Miller, T., Triana, M.D.C., 2009. Demographic diversity in the boardroom: Mediators of the board diversity-firm performance relationship. Journal of Management Studies 46, 755-786.

Netter, J. M., Stegemoller, M., Wintoki, M.B., 2011. Implications of data screens on merger and acquisition analysis: A large sample study of mergers and acquisitions from 1992-2009. Review of Financial Studies 24, 2316-2357.

Nisbett, R.E., Ross, L., 1980. Human Inference: Strategies and Shortcomings of Social Judgment. Englewood Cliffs NJ: Prentice-Hall. 
Paredes, T.A., 2005. Too much pay, too much deference: Behavioral corporate finance, CEOs, and corporate governance. Florida State University Law Review 32, 673-762.

Peterson, R.S., Nemeth, C.J., 1996. Focus versus flexibility: majority and minority influence can both improve performance. Personality and Social Psychology Bulletin 22, 14-23.

Rasmussen, L., Rauner, F., 1996. Industrial cultures and production: Understanding competitiveness. London: Springer.

Rindova, V.P., 1999. What corporate boards have to do with strategy: A cognitive perspective. Journal of Management Studies 36, 953-975.

Roberts, M.R., Whited, T.M., 2013. Endogeneity in empirical corporate finance. Handbook of the Economics of Finance 2A, 493-572.

Schwartz-Ziv, M., 2017. Gender and board activeness: The role of a critical mass. Journal of Financial and Quantitative Analysis 52, 751-780.Simon, M., Houghton, S.M., 2003. The relationship between overconfidence and the introduction of risky products: Evidence from a field study. Academy of Management Journal 46, 139-149.

Weinstein, N.D., 1980. Unrealistic optimism about future life events. Journal of Personality and Social Psychology 39, 806-820.

Westphal, J.D., Milton, L.P., 2000. How experience and network ties affect the influence of demographic minorities on corporate boards. Administrative Science Quarterly 45, 366-398. Wintoki, M.B., Linck, J.S., Netter, J.M., 2012. Endogeneity and the dynamics of internal corporate governance. Journal of Financial Economics 105, 581-606.

Zhou, X.M., 2001. Understanding the determinants of managerial ownership and the link between ownership and performance: comment. Journal of Financial Economics 62, 559-571. 
Table 1

Sample details by year and industry

This table reports the distribution of female directors and the average option-based overconfidence measure, $C E O$ option moneyness, across years and industries. Panel A shows the number and proportion of firms with at least one female director, and those with more than one female director, in addition to the average CEO option moneyness in each year. Panel B reports the same information as Panel A, but across the Fama-French 12 industries (financial firms are excluded).

\begin{tabular}{|c|c|c|c|c|c|c|c|c|}
\hline \multicolumn{9}{|c|}{ Panel A. By year } \\
\hline Year & $\begin{array}{c}\text { No. of } \\
\text { obs. }\end{array}$ & \multicolumn{2}{|c|}{$\begin{array}{l}\text { No. of firm-year } \\
\text { obs. with female } \\
\text { directors }\end{array}$} & \multicolumn{3}{|c|}{$\begin{array}{l}\text { No. of firm-year } \\
\text { obs. with more than one } \\
\text { female directors }\end{array}$} & $\%$ & $\begin{array}{c}\text { Average } \\
\text { CEO option } \\
\text { moneyness }\end{array}$ \\
\hline 1998 & 454 & \multicolumn{2}{|c|}{315} & $69.4 \%$ & \multicolumn{2}{|r|}{108} & $23.8 \%$ & 0.945 \\
\hline 1999 & 620 & \multicolumn{2}{|c|}{412} & $66.5 \%$ & \multicolumn{2}{|r|}{157} & $25.3 \%$ & 1.035 \\
\hline 2000 & 624 & \multicolumn{2}{|c|}{415} & $66.5 \%$ & \multicolumn{2}{|r|}{160} & $25.6 \%$ & 0.941 \\
\hline 2001 & 673 & \multicolumn{2}{|c|}{444} & $66.0 \%$ & \multicolumn{2}{|r|}{163} & $24.2 \%$ & 0.647 \\
\hline 2002 & 678 & \multicolumn{2}{|c|}{482} & $71.1 \%$ & \multicolumn{2}{|r|}{217} & $32.0 \%$ & 0.431 \\
\hline 2003 & 756 & \multicolumn{2}{|c|}{514} & $68.0 \%$ & \multicolumn{2}{|r|}{208} & $27.5 \%$ & 0.662 \\
\hline 2004 & 712 & \multicolumn{2}{|c|}{506} & $71.1 \%$ & \multicolumn{2}{|r|}{219} & $30.8 \%$ & 0.721 \\
\hline 2005 & 734 & \multicolumn{2}{|c|}{532} & $72.5 \%$ & \multicolumn{2}{|r|}{221} & $30.1 \%$ & 0.801 \\
\hline 2006 & 691 & \multicolumn{2}{|c|}{508} & $73.5 \%$ & \multicolumn{2}{|r|}{227} & $32.9 \%$ & 0.770 \\
\hline 2007 & 742 & \multicolumn{2}{|c|}{568} & $76.5 \%$ & \multicolumn{2}{|r|}{318} & $42.9 \%$ & 0.744 \\
\hline 2008 & 703 & \multicolumn{2}{|c|}{517} & $73.5 \%$ & \multicolumn{2}{|r|}{257} & $36.6 \%$ & 0.332 \\
\hline 2009 & 840 & \multicolumn{2}{|c|}{614} & $73.1 \%$ & \multicolumn{2}{|r|}{302} & $36.0 \%$ & 0.392 \\
\hline 2010 & 832 & \multicolumn{2}{|c|}{620} & $74.5 \%$ & & 299 & $35.9 \%$ & 0.543 \\
\hline 2011 & 810 & & 05 & $74.7 \%$ & & 319 & $39.4 \%$ & 0.564 \\
\hline 2012 & 808 & & 98 & $75.2 \%$ & & 318 & $39.4 \%$ & 0.653 \\
\hline 2013 & 760 & & 92 & $77.9 \%$ & & 331 & $43.6 \%$ & 0.823 \\
\hline Total & 11,437 & & 52 & $72.2 \%$ & & 3824 & $33.4 \%$ & 0.688 \\
\hline Panel & B. By Fal & $n-1+4 m$ & 12 mans & & & & & \\
\hline Ind & ustry & $\begin{array}{c}\text { No. of } \\
\text { obs. }\end{array}$ & $\begin{array}{l}\text { No. of } \\
\text { year ob } \\
\text { female d }\end{array}$ & $\begin{array}{l}\text { Irm- } \\
\text { with } \\
\text { ectors }\end{array}$ & $\%$ & $\begin{array}{l}\text { No. of firm-year } \\
\text { obs. with more than } \\
\text { one female directors }\end{array}$ & $\%$ & $\begin{array}{l}\text { Average } \\
\text { CEO option } \\
\text { moneyness }\end{array}$ \\
\hline Non-D & urables & 802 & 67 & & $83.5 \%$ & 460 & $57.4 \%$ & 0.593 \\
\hline Durab & & 340 & 24 & & $70.9 \%$ & 82 & $24.1 \%$ & 0.633 \\
\hline Manuf & acturing & 1855 & 128 & & $69.5 \%$ & 462 & $24.9 \%$ & 0.593 \\
\hline Energy & & 629 & 38 & & $60.6 \%$ & 127 & $20.2 \%$ & 0.742 \\
\hline Chemi & cals & 511 & 42 & & $83.4 \%$ & 239 & $46.8 \%$ & 0.594 \\
\hline Busine & ess Eq. & 2323 & 130 & & $56.2 \%$ & 477 & $20.5 \%$ & 0.741 \\
\hline Teleco & & 183 & 14 & & $77.0 \%$ & 84 & $45.9 \%$ & 0.536 \\
\hline Utiliti & & 748 & 69 & & $92.4 \%$ & 424 & $56.7 \%$ & 0.401 \\
\hline Shops & & 1536 & 127 & & $82.7 \%$ & 689 & $44.9 \%$ & 0.759 \\
\hline Health & care & 1092 & 80 & & $74.0 \%$ & 350 & $32.1 \%$ & 0.824 \\
\hline Other & & 1418 & 102 & & $72.5 \%$ & 430 & $30.3 \%$ & 0.723 \\
\hline Total & & 11,437 & 825 & & $72.2 \%$ & 3824 & $33.4 \%$ & 0.649 \\
\hline
\end{tabular}


Table 2

Descriptive statistics




test for differences in the means (medians). $* * *, * *$ and $*$ indicate significance at the $1 \%, 5 \%$, and $10 \%$ level, respectively.

\begin{tabular}{|c|c|c|c|c|c|c|c|c|}
\hline \multirow[b]{3}{*}{ Variables } & \multirow{2}{*}{\multicolumn{2}{|c|}{ Whole sample }} & \multirow{2}{*}{\multicolumn{2}{|c|}{$\begin{array}{c}\text { Firm-year obs. } \\
\text { with female } \\
\text { directors }\end{array}$}} & \multirow{2}{*}{\multicolumn{2}{|c|}{$\begin{array}{c}\begin{array}{c}\text { Firm-year obs. } \\
\text { without female } \\
\text { directors }\end{array} \\
\mathrm{N}=3544\end{array}$}} & \multicolumn{2}{|c|}{ Difference } \\
\hline & & & & & & & \multirow[b]{2}{*}{ Mean } & \multirow[b]{2}{*}{ Median } \\
\hline & Mean & Median & \multirow[t]{2}{*}{ Mean } & \multirow[t]{2}{*}{ Median } & Mean & Median & & \\
\hline \multicolumn{7}{|l|}{ Main variables } & & \\
\hline CEO option moneyness & 0.686 & 0.337 & 0.620 & 0.314 & 0.828 & 0.392 & $-0.208 * * *$ & $-0.078 * * *$ \\
\hline Fraction of female directors & 0.104 & 0.100 & 0.153 & 0.125 & 0.000 & 0.000 & $0.153 * * *$ & $0.125 * * *$ \\
\hline \multicolumn{9}{|l|}{ Firm characteristics } \\
\hline Sales (million \$) & 5619.7 & 1623.8 & 7524.9 & 2499.6 & 1548.8 & 699.3 & $5976.1 * * *$ & $1800.3 * * *$ \\
\hline Leverage & 0.225 & 0.223 & 0.242 & 0.241 & 0.189 & 0.172 & $0.053 * * *$ & $0.069 * * *$ \\
\hline Stock return & 0.130 & 0.089 & 0.123 & 0.093 & 0.145 & 0.080 & $-0.021 * *$ & 0.012 \\
\hline $\mathrm{ROA}$ & 0.143 & 0.136 & 0.147 & 0.139 & 0.132 & 0.131 & $0.015 * * *$ & $0.008 * * *$ \\
\hline Tobin's q & 1.930 & 1.542 & 1.896 & 1.518 & 2.004 & 1.597 & $-0.108 * * *$ & $-0.079 * * *$ \\
\hline \multicolumn{9}{|c|}{ Governance and board characteristics } \\
\hline Board independence & 0.726 & 0.750 & 0.749 & 0.778 & 0.675 & 0.714 & $0.075 * * *$ & $0.063 * * *$ \\
\hline Board size & 9.368 & 9.000 & 10.122 & 10.000 & 7.757 & 8.000 & $2.365 * * *$ & $2.000 * * *$ \\
\hline E index & 2.571 & 3.000 & 2.674 & 3.000 & 2.350 & 2.000 & $0.324 * * *$ & $1.000 * * *$ \\
\hline \multicolumn{9}{|l|}{ CEO characteristics } \\
\hline CEO age & 55.612 & 56.000 & 55.806 & 56.000 & 55.197 & 55.000 & $0.609 * * *$ & $1.000 * * *$ \\
\hline CEO Chairman & 0.613 & 1.000 & 0.655 & 1.000 & 0.524 & 1.000 & $0.131 * * *$ & $0.000 * * *$ \\
\hline CEO tenure & 8.213 & 6.000 & 7.443 & 6.000 & 9.857 & 7.000 & $-2.414 * * *$ & $-1.000 * * *$ \\
\hline CEO ownership & 0.015 & 0.003 & 0.011 & 0.002 & 0.023 & 0.004 & $-0.013 * * *$ & $-0.002 * * *$ \\
\hline MBA & 0.379 & 0.000 & 0.401 & 0.000 & 0.333 & 0.000 & $0.068 * * *$ & $0.000 * * *$ \\
\hline Age first CEO role & 46.486 & 47.000 & 47.309 & 48.000 & 44.725 & 45.000 & $2.585 * * *$ & $3.000 * * *$ \\
\hline Qualification & 0.084 & 0.000 & 0.085 & 0.000 & 0.082 & 0.000 & 0.003 & 0.000 \\
\hline
\end{tabular}


Military experience

Ivy League
0.066

0.193
0.000 0.000
0.073 0.202
0.000 0.000
0.051 0.174
0.000 0.000
$0.023 * * *$ $0.028 * * *$

$0.000 * * *$ $0.000 * * *$ 
Table 3

Female board representation and CEO option moneyness

This table examines how female board representation affects the CEO's option holding and exercise behavior. Panel A presents OLS regression results for the male and female CEO samples. The dependent variable is the CEO's stock option moneyness (CEO option moneyness). Variable definitions are provided in the Appendix. Panel B presents regression results based on alternative modelling techniques for the male CEO sample. Regressions (1) to (3) use CEO option moneyness as the dependent variable, while regressions (4) and (5) use Confident $C E O$ as the dependent variable, where Confident $C E O$ is an indicator variable that equals one if the CEO's option moneyness is greater than 100\% (or 67\%), and zero otherwise. The regressions in Panel B include the same firm, governance, and CEO characteristics as regression (3) of Panel A. However, only the regression coefficient on the main variable of interest, Fraction of female directors, is reported for brevity. Industry effects are constructed based on the Fama-French 49-industry classification. Statistical significance is based on the heteroskedasticity robust firm-clustered standard errors reported in parentheses. The t-statistics for the FamaMacBeth regressions are computed using the Newey-West standard errors. ***, ** and * indicate significance at the $1 \%, 5 \%$ and $10 \%$ level, respectively.

Panel A. OLS regression results for the male and female CEO samples

Dependent variable: CEO option moneyness

\begin{tabular}{|c|c|c|c|c|}
\hline & \multicolumn{3}{|c|}{ Male CEO sample } & \multirow{2}{*}{$\frac{\text { Female CEO sample }}{(4)}$} \\
\hline & (1) & (2) & (3) & \\
\hline Fraction of female directors & $\begin{array}{c}-0.943 * * * \\
(0.174)\end{array}$ & $\begin{array}{c}-0.836 * * * \\
(0.170)\end{array}$ & $\begin{array}{c}-0.624 * * * \\
(0.167)\end{array}$ & $\begin{array}{c}0.229 \\
(0.377)\end{array}$ \\
\hline Ln(Sales) & - & $\begin{array}{l}-0.013 \\
(0.011)\end{array}$ & $\begin{array}{c}0.020 \\
(0.014)\end{array}$ & $\begin{array}{c}-0.065 \\
(0.042)\end{array}$ \\
\hline Leverage & - & $\begin{array}{l}-0.006 \\
(0.097)\end{array}$ & $\begin{array}{c}0.026 \\
(0.097)\end{array}$ & $\begin{array}{c}0.333 \\
(0.283)\end{array}$ \\
\hline Stock return & - & $\begin{array}{c}0.526 * * * \\
(0.032)\end{array}$ & $\begin{array}{c}0.525 * * * \\
(0.032)\end{array}$ & $\begin{array}{l}0.234 * \\
(0.122)\end{array}$ \\
\hline ROA & - & $\begin{array}{c}0.878 * * * \\
(0.244)\end{array}$ & $\begin{array}{c}0.860 * * * \\
(0.245)\end{array}$ & $\begin{array}{c}0.509 \\
(0.785)\end{array}$ \\
\hline Tobin's q & - & $\begin{array}{c}0.214 * * * \\
(0.023)\end{array}$ & $\begin{array}{c}0.210 * * * \\
(0.023)\end{array}$ & $\begin{array}{l}0.209 * * \\
(0.095)\end{array}$ \\
\hline Board independence & - & - & $\begin{array}{l}-0.126 \\
(0.117)\end{array}$ & $\begin{array}{c}0.701 \\
(0.591)\end{array}$ \\
\hline Board size & - & - & $\begin{array}{c}-0.030 * * * \\
(0.007)\end{array}$ & $\begin{array}{c}-0.066^{*} \\
(0.035)\end{array}$ \\
\hline E index & - & - & $\begin{array}{c}-0.008 \\
(0.013)\end{array}$ & $\begin{array}{c}-0.039 \\
(0.032)\end{array}$ \\
\hline CEO age & - & - & $\begin{array}{c}0.002 \\
(0.003)\end{array}$ & $\begin{array}{c}0.013 \\
(0.011)\end{array}$ \\
\hline CEO Chairman & - & - & $\begin{array}{l}-0.017 \\
(0.030)\end{array}$ & $\begin{array}{c}-0.297 * * \\
(0.123)\end{array}$ \\
\hline CEO tenure & - & - & $\begin{array}{l}0.005 * \\
(0.003)\end{array}$ & $\begin{array}{c}-0.002 \\
(0.008)\end{array}$ \\
\hline CEO ownership & - & - & $\begin{array}{c}0.534 \\
(0.397)\end{array}$ & $\begin{array}{c}1.165 \\
(1.156)\end{array}$ \\
\hline MBA & - & - & $\begin{array}{l}0.058 * \\
(0.030)\end{array}$ & $\begin{array}{c}-0.280 * * \\
(0.128)\end{array}$ \\
\hline Age first $\mathrm{CEO}$ role & - & - & $\begin{array}{l}-0.004 \\
(0.003)\end{array}$ & $\begin{array}{c}0.002 \\
(0.010)\end{array}$ \\
\hline
\end{tabular}


Qualification

Military experience

Ivy League

Industry effects

Year effects

Number of observations

Adjusted R ${ }^{2}$

$\begin{array}{cccc}- & - & 0.009 & 0.438 * * \\ - & & (0.057) & (0.175) \\ & - & 0.022 & 0.078 \\ - & - & (0.057) & (0.204) \\ & & 0.030 & 0.018 \\ & & (0.038) & (0.150)\end{array}$

Yes

Yes

Yes

Yes

Yes

11,113

Yes

Yes

Yes

322

0.070

0.216

0.224 
Panel B. Alternative modelling techniques using the male CEO sample

Dependent variables

\begin{tabular}{|c|c|c|c|c|c|c|}
\hline & \multicolumn{4}{|c|}{ CEO option moneyness } & \multirow{2}{*}{$\begin{array}{c}\begin{array}{c}\text { Overconfident CEO } \\
\text { (moneyness }>100 \%)\end{array} \\
\text { Logit } \\
(5)\end{array}$} & \multirow{2}{*}{$\begin{array}{c}\begin{array}{c}\text { Overconfident CEO } \\
\text { (moneyness }>67 \%)\end{array} \\
\text { Logit } \\
(6)\end{array}$} \\
\hline & $\begin{array}{l}\text { Firm FE } \\
\text { (1) }\end{array}$ & $\begin{array}{c}\text { Fama and MacBeth } \\
\text { (2) }\end{array}$ & $\begin{array}{l}\text { CEO-Firm FE } \\
\text { (3) }\end{array}$ & $\begin{array}{c}\text { CEO-Firm FE (>1 change) } \\
\text { (4) }\end{array}$ & & \\
\hline Fraction of female directors & $\begin{array}{c}-0.615^{* * *} \\
(0.235)\end{array}$ & $\begin{array}{c}-0.566^{* * *} \\
(0.102)\end{array}$ & $\begin{array}{l}-0.053 \\
(0.236)\end{array}$ & $\begin{array}{c}-0.351^{* *} \\
(0.161)\end{array}$ & $\begin{array}{l}-1.854 * * * \\
(0.544)\end{array}$ & $\begin{array}{l}-1.691 * * * \\
(0.460)\end{array}$ \\
\hline All controls & Yes & Yes & Yes & Yes & Yes & Yes \\
\hline CEO-firm effects & No & No & Yes & Yes & No & No \\
\hline Firm fixed effects & Yes & No & No & No & No & No \\
\hline Industry effects & No & Yes & Yes & Yes & Yes & Yes \\
\hline Year effects & Yes & No & Yes & Yes & Yes & Yes \\
\hline Number of observations & 11,113 & 11,113 & 11,113 & 4,123 & 11,113 & 11,113 \\
\hline Adjusted $\mathrm{R}^{2} /$ Average $\mathrm{R}^{2}$ & 0.197 & 0.315 & 0.171 & 0.194 & - & - \\
\hline Pseudo $\mathrm{R}^{2}$ & - & - & - & - & 0.174 & 0.154 \\
\hline
\end{tabular}




\section{Table 4}

\section{Propensity score matching estimates}

This table reports the propensity score matching estimation results for the male CEO sample. Panel A reports parameter estimates from the logit model used to estimate propensity scores. The dependent variable is an indicator variable for the presence of female directors in a firm for a given year. All independent variables are defined in the appendix. Industry effects are constructed based on the Fama-French 49-industry classification. Statistical significance is based on the heteroskedasticity robust firm-clustered standard errors reported in parentheses. Panel B reports the univariate comparisons of firm characteristics between firms with and without female directors and the corresponding t-statistics. Panel $\mathrm{C}$ reports the average treatment effect estimates. $C E O$ option moneyness is the CEO's estimated stock option moneyness. ***, ** and * indicate significance at the $1 \%$, $5 \%$ and $10 \%$ level, respectively.

Panel A. Prematch propensity score regression and postmatch diagnostic regression

Dependent variable:

Dummy equals 1 if female directors are on the board and 0 otherwise

\begin{tabular}{|c|c|}
\hline $\begin{array}{l}\text { Prematch } \\
\text { (1) }\end{array}$ & $\begin{array}{c}\text { Postmatch } \\
\text { (2) }\end{array}$ \\
\hline $0.408 * * *$ & -0.028 \\
\hline$(0.049)$ & $(0.052)$ \\
\hline 0.243 & 0.172 \\
\hline$(0.315)$ & $(0.332)$ \\
\hline$-0.115^{*}$ & 0.055 \\
\hline$(0.062)$ & $(0.073)$ \\
\hline 0.528 & 0.120 \\
\hline$(0.591)$ & $(0.641)$ \\
\hline 0.073 & -0.001 \\
\hline$(0.048)$ & $(0.056)$ \\
\hline $2.209 * * *$ & -0.216 \\
\hline$(0.332)$ & $(0.360)$ \\
\hline $0.404 * * *$ & -0.004 \\
\hline$(0.032)$ & $(0.032)$ \\
\hline $0.100 * *$ & -0.005 \\
\hline$(0.044)$ & $(0.047)$ \\
\hline 0.003 & -0.003 \\
\hline$(0.011)$ & $(0.011)$ \\
\hline $0.399 * * *$ & -0.016 \\
\hline$(0.102)$ & $(0.110)$ \\
\hline$-0.037 * * *$ & 0.005 \\
\hline$(0.011)$ & $(0.011)$ \\
\hline-1.511 & -0.326 \\
\hline (1.136) & (1.224) \\
\hline 0.166 & -0.001 \\
\hline$(0.107)$ & $(0.118)$ \\
\hline-0.007 & -0.002 \\
\hline$(0.011)$ & $(0.011)$ \\
\hline-0.218 & -0.023 \\
\hline$(0.186)$ & $(0.196)$ \\
\hline 0.130 & 0.003 \\
\hline$(0.214)$ & $(0.255)$ \\
\hline 0.048 & -0.023 \\
\hline$(0.136)$ & $(0.150)$ \\
\hline Yes & Yes \\
\hline Yes & Yes \\
\hline 11,091 & 4,500 \\
\hline 0.294 & 0.003 \\
\hline
\end{tabular}


Panel B. Differences in firm characteristics

\begin{tabular}{|c|c|c|c|c|}
\hline Variables & $\begin{array}{l}\text { Firm-year obs. } \\
\text { with female dirs. } \\
\quad(\mathrm{N}=2,250)\end{array}$ & $\begin{array}{c}\text { Firm-year obs. } \\
\text { without female dirs. } \\
(\mathrm{N}=2,250)\end{array}$ & Difference & t-statistics \\
\hline Ln(Sales) & 6.928 & 6.970 & -0.042 & -1.153 \\
\hline Leverage & 0.211 & 0.210 & 0.001 & 0.168 \\
\hline Stock return & 0.141 & 0.130 & 0.011 & 0.772 \\
\hline $\mathrm{ROA}$ & 0.135 & 0.136 & -0.001 & -0.140 \\
\hline Tobin's q & 1.927 & 1.909 & 0.018 & 0.514 \\
\hline Board independence & 0.705 & 0.707 & -0.002 & -0.298 \\
\hline Board size & 8.480 & 8.508 & -0.028 & -0.535 \\
\hline E index & 2.527 & 2.543 & -0.016 & -0.429 \\
\hline CEO age & 55.028 & 55.138 & -0.110 & -0.524 \\
\hline CEO Chairman & 0.543 & 0.547 & -0.004 & -0.269 \\
\hline CEO tenure & 8.750 & 8.553 & 0.197 & 0.933 \\
\hline CEO ownership & 0.015 & 0.016 & -0.001 & -0.055 \\
\hline MBA & 0.352 & 0.352 & 0.000 & 0.031 \\
\hline Age first CEO role & 45.442 & 45.707 & -0.265 & -1.171 \\
\hline Qualification & 0.088 & 0.090 & -0.001 & -0.157 \\
\hline Military experience & 0.055 & 0.056 & -0.001 & -0.131 \\
\hline Ivy League & 0.181 & 0.182 & -0.001 & -0.077 \\
\hline
\end{tabular}

Panel C. Propensity Score Matching Estimator

\begin{tabular}{|c|c|c|c|c|}
\hline Variables & $\begin{array}{l}\text { Firm-year obs. } \\
\text { with female dirs. } \\
\quad(\mathrm{N}=2,250)\end{array}$ & $\begin{array}{l}\text { Firm-year obs. } \\
\text { without female dirs. } \\
\qquad(\mathrm{N}=2,250)\end{array}$ & Difference & t-statistics \\
\hline CEO option moneyness & 0.696 & 0.776 & $-0.081 * * *$ & -2.510 \\
\hline
\end{tabular}




\section{Table 5}

\section{Instrumental variables estimates}

This table presents estimates of the instrumental variables method using two-stage least square (2SLS) panel regressions. The dependent variable is the fraction of female directors and CEO option moneyness for the first and second stage regressions, respectively. The instrumental variables are as follows. Fraction of male directors linked to female directors is the fraction of male directors on the board who sit on other boards with at least one female director. Female-to-male population ratio is calculated as the female population divided by the male population in the state where the firm has its headquarters. All other variables are defined in the appendix. Industry and year effects are included. Industry effects are constructed based on the Fama-French 49-industry classification. Statistical significance is based on the heteroskedasticity robust firmclustered standard errors reported in brackets. $* * * * *$ and $*$ indicate significance at the $1 \%, 5 \%$ and $10 \%$ level, respectively.

\begin{tabular}{|c|c|c|c|c|c|c|}
\hline & \multicolumn{6}{|c|}{ Dependent variables } \\
\hline & $\begin{array}{c}\text { Fraction female } \\
\text { directors }\end{array}$ & $\begin{array}{l}\text { CEO option } \\
\text { moneyness }\end{array}$ & $\begin{array}{c}\text { Fraction female } \\
\text { directors }\end{array}$ & $\begin{array}{l}\text { CEO option } \\
\text { moneyness }\end{array}$ & $\begin{array}{c}\text { Fraction female } \\
\text { directors }\end{array}$ & $\begin{array}{l}\text { CEO option } \\
\text { moneyness }\end{array}$ \\
\hline & $\begin{array}{l}\text { First stage } \\
\text { (1) }\end{array}$ & $\begin{array}{c}\text { Second stage } \\
\text { (2) }\end{array}$ & $\begin{array}{c}\text { First stage } \\
\text { (3) }\end{array}$ & $\begin{array}{l}\text { Second stage } \\
\text { (4) }\end{array}$ & $\begin{array}{c}\text { First stage } \\
(5)\end{array}$ & $\begin{array}{c}\text { Second stage } \\
\text { (6) }\end{array}$ \\
\hline Fraction male linked to female, $\mathrm{z}_{1}$ & $\begin{array}{c}0.029 * * * \\
(0.009)\end{array}$ & - & $\begin{array}{c}0.038 * * * \\
(0.010)\end{array}$ & - & $\begin{array}{c}0.084 * * * \\
(0.009)\end{array}$ & - \\
\hline Female-to-male population ratio, $\mathrm{z}_{2}$ & $\begin{array}{c}0.211 * * * \\
(0.074)\end{array}$ & - & $\begin{array}{c}0.212 * * * \\
(0.074)\end{array}$ & - & $\begin{array}{c}0.203 * * * \\
(0.072)\end{array}$ & - \\
\hline Fraction of female directors & - & $\begin{array}{c}-6.672 * * * \\
(2.365)\end{array}$ & - & $\begin{array}{c}-4.991 * * * \\
(1.931)\end{array}$ & - & $\begin{array}{c}-3.814 * * * \\
(1.003)\end{array}$ \\
\hline Ln(Sales) & $\begin{array}{c}0.012 * * * \\
(0.002)\end{array}$ & $\begin{array}{c}0.106 * * * \\
(0.037)\end{array}$ & $\begin{array}{c}0.012 * * * \\
(0.002)\end{array}$ & $\begin{array}{c}0.095 * * * \\
(0.031)\end{array}$ & $\begin{array}{c}0.014 * * * \\
(0.002)\end{array}$ & $\begin{array}{c}0.085 * * * \\
(0.023)\end{array}$ \\
\hline Leverage & $\begin{array}{c}0.014 \\
(0.011)\end{array}$ & $\begin{array}{c}0.112 \\
(0.114)\end{array}$ & $\begin{array}{c}0.014 \\
(0.011)\end{array}$ & $\begin{array}{c}0.100 \\
(0.105)\end{array}$ & $\begin{array}{l}0.018 * \\
(0.010)\end{array}$ & $\begin{array}{c}0.094 \\
(0.100)\end{array}$ \\
\hline Stock return & $\begin{array}{c}-0.004 * * \\
(0.002)\end{array}$ & $\begin{array}{c}0.502 * * * \\
(0.036)\end{array}$ & $\begin{array}{c}-0.004 * * \\
(0.002)\end{array}$ & $\begin{array}{c}0.505 * * * \\
(0.035)\end{array}$ & $\begin{array}{c}-0.005 * * * \\
(0.002)\end{array}$ & $\begin{array}{c}0.508 * * * \\
(0.033)\end{array}$ \\
\hline ROA & $\begin{array}{l}-0.015 \\
(0.020)\end{array}$ & $\begin{array}{c}0.712 * * * \\
(0.269)\end{array}$ & $\begin{array}{l}-0.017 \\
(0.020)\end{array}$ & $\begin{array}{c}0.697 * * * \\
(0.257)\end{array}$ & $\begin{array}{l}-0.030 \\
(0.019)\end{array}$ & $\begin{array}{c}0.684 * * * \\
(0.251)\end{array}$ \\
\hline Tobin's q & $\begin{array}{c}0.002 \\
(0.002)\end{array}$ & $\begin{array}{l}0.221 * * * \\
(0.024)\end{array}$ & $\begin{array}{c}0.002 \\
(0.002)\end{array}$ & $\begin{array}{c}0.221 * * * \\
(0.023)\end{array}$ & $\begin{array}{c}0.003 * * \\
(0.001)\end{array}$ & $\begin{array}{c}0.220 * * * \\
(0.023)\end{array}$ \\
\hline Board independence & $\begin{array}{c}0.077 * * * \\
(0.011)\end{array}$ & $\begin{array}{c}0.393 \\
(0.245)\end{array}$ & $\begin{array}{c}0.079 * * * \\
(0.011)\end{array}$ & $\begin{array}{c}0.311 \\
(0.209)\end{array}$ & $\begin{array}{c}0.089 * * * \\
(0.011)\end{array}$ & $\begin{array}{c}0.249 \\
(0.155)\end{array}$ \\
\hline
\end{tabular}




\begin{tabular}{|c|c|c|c|c|c|c|}
\hline Board size & $\begin{array}{c}0.004 * * * \\
(0.001)\end{array}$ & $\begin{array}{c}-0.002 \\
(0.014)\end{array}$ & $\begin{array}{c}0.005^{* * *} * \\
(0.001)\end{array}$ & $\begin{array}{c}-0.003 \\
(0.013)\end{array}$ & $\begin{array}{c}0.007 * * * \\
(0.001)\end{array}$ & $\begin{array}{c}-0.004 \\
(0.010)\end{array}$ \\
\hline \multirow[t]{2}{*}{ E index } & $0.002 *$ & 0.008 & $0.002 *$ & 0.004 & $0.002 *$ & 0.002 \\
\hline & $(0.001)$ & $(0.015)$ & $(0.001)$ & $(0.014)$ & $(0.001)$ & $(0.013)$ \\
\hline \multirow[t]{2}{*}{ CEO age } & 0.000 & 0.004 & 0.000 & 0.004 & 0.000 & 0.004 \\
\hline & $(0.000)$ & $(0.004)$ & $(0.000)$ & $(0.004)$ & $(0.000)$ & $(0.004)$ \\
\hline \multirow[t]{2}{*}{ CEO Chairman } & $0.013 * * *$ & 0.068 & $0.013 * * *$ & 0.049 & $0.013 * * *$ & 0.034 \\
\hline & $(0.003)$ & $(0.048)$ & $(0.003)$ & $(0.043)$ & $(0.003)$ & $(0.035)$ \\
\hline \multirow[t]{2}{*}{ CEO tenure } & $-0.001 * * *$ & -0.004 & $-0.002 * * *$ & -0.002 & $-0.002 * * *$ & -0.000 \\
\hline & $(0.000)$ & $(0.005)$ & $(0.000)$ & $(0.004)$ & $(0.000)$ & $(0.004)$ \\
\hline \multirow[t]{2}{*}{ CEO ownership } & -0.015 & 0.231 & -0.014 & 0.254 & -0.013 & 0.264 \\
\hline & $(0.038)$ & $(0.410)$ & $(0.038)$ & $(0.382)$ & $(0.037)$ & $(0.370)$ \\
\hline \multirow[t]{2}{*}{ MBA } & $0.006 *$ & $0.091 * *$ & $0.006^{*}$ & $0.083 * *$ & $0.006 *$ & $0.076 * *$ \\
\hline & $(0.003)$ & $(0.038)$ & $(0.003)$ & $(0.035)$ & $(0.003)$ & $(0.033)$ \\
\hline \multirow[t]{2}{*}{ Age first CEO role } & -0.000 & -0.006 & -0.000 & -0.005 & -0.000 & -0.005 \\
\hline & $(0.000)$ & $(0.004)$ & $(0.000)$ & $(0.003)$ & $(0.000)$ & $(0.003)$ \\
\hline \multirow[t]{2}{*}{ Qualification } & -0.005 & -0.013 & -0.005 & -0.007 & -0.006 & 0.001 \\
\hline & $(0.006)$ & $(0.070)$ & $(0.006)$ & $(0.065)$ & $(0.006)$ & $(0.061)$ \\
\hline \multirow[t]{2}{*}{ Military experience } & $0.017 * *$ & 0.131 & $0.017 * *$ & 0.101 & $0.016 * *$ & 0.078 \\
\hline & $(0.007)$ & $(0.085)$ & $(0.007)$ & $(0.076)$ & $(0.007)$ & $(0.065)$ \\
\hline \multirow[t]{2}{*}{ Ivy League } & 0.001 & 0.053 & 0.001 & 0.051 & 0.001 & 0.049 \\
\hline & $(0.004)$ & $(0.045)$ & $(0.004)$ & $(0.041)$ & $(0.004)$ & $(0.040)$ \\
\hline \multirow[t]{2}{*}{ No. external board seats } & - & - & $-0.001 * *$ & $-0.008 * * *$ & - & - \\
\hline & & & $(0.000)$ & $(0.003)$ & & \\
\hline \multirow[t]{2}{*}{ No. male external board seats } & - & - & - & - & $-0.004 * * *$ & $-0.015 * * *$ \\
\hline & & & & & $(0.000)$ & $(0.004)$ \\
\hline Industry effects & Yes & Yes & Yes & Yes & Yes & Yes \\
\hline Year effects & Yes & Yes & Yes & Yes & Yes & Yes \\
\hline Number of observations & 10,844 & 10,844 & 10,844 & 10,844 & 10,844 & 10,844 \\
\hline F-statistic $\left(\mathrm{z}_{1}=\mathrm{z}_{2}=0\right)$ & $9.120 * * *$ & - & $11.380 * * *$ & - & $45.010 * * *$ & - \\
\hline CD Wald F-statistic & 45.610 & - & 51.630 & - & 165.740 & - \\
\hline Hansen's $J$ test $p$-value & - & 0.170 & - & 0.260 & - & 0.647 \\
\hline
\end{tabular}




\section{Table 6}

Changes in CEO option moneyness around director appointments

This table reports the results of the difference-in-differences analysis for the male CEO sample. The dependent variable is the CEO's stock option moneyness. Female appointment is an indicator variable that equals one if the firm appoint a female director, and zero otherwise. Post is a dummy variable that equals one in the period after the appointment, and zero otherwise. Post ${ }_{-2}$, Post ${ }_{-1}$, Post ${ }_{+1}$, and Post ${ }_{+2}$ are indicator variables for the second year prior to, the first year prior to, the first year after, and the second year after the appointment, respectively. Variable definitions are provided in the Appendix. The other control variables are the same as for regression (3) of Panel A in Table 3. Industry effects are constructed based on the Fama-French 49-industry classification. Statistical significance is based on the heteroskedasticity robust firm-clustered standard errors reported in brackets. $* * *, * *$ and $*$ indicate significance at the $1 \%, 5 \%$ and $10 \%$ level, respectively.

\begin{tabular}{|c|c|c|c|c|c|}
\hline & \multicolumn{5}{|c|}{ Dependent variable: CEO option moneyness } \\
\hline & $\begin{array}{c}\text { OLS } \\
{[-1,+1]} \\
(1)\end{array}$ & $\begin{array}{c}\text { OLS } \\
{[-1,+1]} \\
(2)\end{array}$ & $\begin{array}{c}\text { Pair FE } \\
{[-1,+1]} \\
\quad(3)\end{array}$ & $\begin{array}{c}\text { OLS } \\
{[-2,+2]} \\
(4)\end{array}$ & $\begin{array}{c}\text { Pair FE } \\
{[-2,+2]} \\
(5)\end{array}$ \\
\hline Female appointment & $\begin{array}{c}-0.074 \\
(0.158)\end{array}$ & $\begin{array}{c}-0.049 \\
(0.195)\end{array}$ & - & - & - \\
\hline Post & $\begin{array}{l}0.207 * \\
(0.121)\end{array}$ & $\begin{array}{c}0.219 * \\
(0.120)\end{array}$ & $\begin{array}{c}0.029 \\
(0.458)\end{array}$ & $\begin{array}{c}0.273 * * \\
(0.114)\end{array}$ & $\begin{array}{c}0.387 * * \\
(0.170)\end{array}$ \\
\hline Female appointment $\times$ Post & $\begin{array}{c}-0.282 * * \\
(0.135)\end{array}$ & $\begin{array}{c}-0.301 * * \\
(0.136)\end{array}$ & $\begin{array}{c}-0.251 * * \\
(0.097)\end{array}$ & - & - \\
\hline Female appointment $\times$ Post $_{-2}$ & - & - & - & $\begin{array}{c}0.162 \\
(0.152)\end{array}$ & - \\
\hline Female appointment $\times$ Post $_{-1}$ & - & - & - & $\begin{array}{c}0.031 \\
(0.128)\end{array}$ & $\begin{array}{c}-0.047 \\
(0.101)\end{array}$ \\
\hline Female appointment $\times$ Post +1 & - & - & - & $\begin{array}{c}-0.265 * * \\
(0.119)\end{array}$ & $\begin{array}{c}-0.331 * * \\
(0.137)\end{array}$ \\
\hline Female appointment $\times$ Post +2 & - & - & - & $\begin{array}{c}-0.308 * * \\
(0.150)\end{array}$ & $\begin{array}{c}-0.343 * \\
(0.174)\end{array}$ \\
\hline Dummy_MBA replaces non-MBA & - & $\begin{array}{l}-0.044 \\
(0.177)\end{array}$ & - & - & - \\
\hline
\end{tabular}


Dummy_Ivy replaces non-Ivy

$(0.283)$

Dummy_Non-Ivy replaces Ivy

$-0.049$

Dummy_Qualif. replaces non-Qualif.

$(0.227)$

Dummy_Non-Qualif. replaces Qualif.

$-0.008$

$(0.167)$

$-0.114$

$(0.311)$

All controls

Director-pair effects

Industry effects

Year effects

Number of observations

Yes

Yes

No

Yes

Yes

224

Adjusted $\mathrm{R}^{2}$

224

0.381

$\begin{array}{ccc}\text { Yes } & \text { Yes } & \text { Yes } \\ \text { Yes } & \text { No } & \text { Yes } \\ \text { No } & \text { Yes } & \text { No } \\ \text { Yes } & \text { Yes } & \text { Yes } \\ 224 & 360 & 360 \\ 0.518 & 0.360 & 0.368\end{array}$




\section{Table 7}

Female board representation, overconfidence, and corporate investment

This table contains regression models that examine the relation between female board representation, overconfidence, investment, and investment cash flows sensitivity. The dependent variable, Capital expenditures, is defined as the firm's capital expenditures in year $\mathrm{t}+1$ scaled by net property, plant and equipment in year $\mathrm{t}$. Variable definitions are provided in the Appendix. The other control variables are the same as for regression (3) of Panel A in Table 3. Industry effects are constructed based on the Fama-French 49industry classification. Statistical significance is based on the heteroskedasticity robust firm-clustered standard errors reported in parentheses. $* * * * *$ and $*$ indicate significance at the $1 \%, 5 \%$ and $10 \%$ level, respectively.

\begin{tabular}{|c|c|c|c|c|c|c|}
\hline & \multicolumn{6}{|c|}{ Dependent variable: Capital expenditures $\left(\mathrm{CAPEX}_{\mathrm{t}+1} / \mathrm{PPE}_{\mathrm{t}}\right)$} \\
\hline & \multicolumn{2}{|c|}{ Whole sample } & \multicolumn{2}{|c|}{ High industry OC representation } & \multicolumn{2}{|c|}{ Low industry OC representation } \\
\hline & $\begin{array}{l}\text { OLS } \\
(1)\end{array}$ & $\begin{array}{l}\text { Firm FE } \\
\text { (2) }\end{array}$ & $\begin{array}{l}\text { OLS } \\
(3)\end{array}$ & $\begin{array}{l}\text { Firm FE } \\
\text { (4) }\end{array}$ & $\begin{array}{l}\text { OLS } \\
(5)\end{array}$ & $\begin{array}{l}\text { Firm FE } \\
\quad(6)\end{array}$ \\
\hline Lagged capital expenditures & $\begin{array}{c}0.239 * * * \\
(0.058)\end{array}$ & $\begin{array}{c}0.003 \\
(0.072)\end{array}$ & $\begin{array}{c}0.164 * * * \\
(0.055)\end{array}$ & $\begin{array}{l}-0.252 * \\
(0.135)\end{array}$ & $\begin{array}{l}0.385 * * * \\
(0.057)\end{array}$ & $\begin{array}{c}0.063 \\
(0.064)\end{array}$ \\
\hline Fraction of female directors & $\begin{array}{c}0.044 \\
(0.035)\end{array}$ & $\begin{array}{c}0.039 \\
(0.047)\end{array}$ & $\begin{array}{c}0.191 \\
(0.123)\end{array}$ & $\begin{array}{l}0.440 * \\
(0.241)\end{array}$ & $\begin{array}{c}0.055 \\
(0.048)\end{array}$ & $\begin{array}{c}0.080 \\
(0.069)\end{array}$ \\
\hline High industry OC representation & $\begin{array}{l}0.046 * * * \\
(0.012)\end{array}$ & $\begin{array}{c}0.039 * * * \\
(0.013)\end{array}$ & - & - & - & - \\
\hline $\begin{array}{l}\text { Fraction of female directors } \\
\quad \times \text { High industry OC representation }\end{array}$ & $\begin{array}{c}-0.131 * * \\
(0.065)\end{array}$ & $\begin{array}{c}-0.114^{*} \\
(0.068)\end{array}$ & - & - & - & - \\
\hline Cash flow & - & - & $\begin{array}{c}0.376 * * \\
(0.172)\end{array}$ & $\begin{array}{c}0.916 * * \\
(0.385)\end{array}$ & $\begin{array}{c}0.076 \\
(0.053)\end{array}$ & $\begin{array}{c}0.307 * * * \\
(0.090)\end{array}$ \\
\hline Fraction of female directors $\times$ Cash flow & - & - & $\begin{array}{c}-1.989 * \\
(1.144)\end{array}$ & $\begin{array}{l}-2.936 * \\
(1.778)\end{array}$ & $\begin{array}{l}-0.382 \\
(0.362)\end{array}$ & $\begin{array}{c}-0.874 \\
(0.552)\end{array}$ \\
\hline All controls & Yes & Yes & Yes & Yes & Yes & Yes \\
\hline Industry effects & Yes & No & Yes & No & Yes & No \\
\hline Year effects & Yes & Yes & Yes & Yes & Yes & Yes \\
\hline Number of observations & 8,802 & 8,802 & 4,133 & 4,133 & 4,669 & 4,669 \\
\hline Adjusted $\mathrm{R}^{2}$ & 0.195 & 0.033 & 0.167 & 0.142 & 0.354 & 0.086 \\
\hline
\end{tabular}




\section{Table 8}

Female board representation, overconfidence and merger activities

This table contains regression models that examine the relation between female board representation, overconfidence and merger activities. The dependent variable is the acquirer's cumulative abnormal returns from five days before the acquisition announcement to five days after. Variable definitions are provided in the Appendix. The other control variables are the same as for regression (3) of Panel A in Table 3. Industry effects are constructed based on the Fama-French 49-industry classification. Statistical significance is based on the heteroskedasticity robust firm-clustered standard errors reported in parentheses. $* * * * *$ and $*$ indicate significance at the $1 \%, 5 \%$ and $10 \%$ level, respectively.

\section{Dependent variable: CAR $[-5,+5]$}

\begin{tabular}{lcc}
\hline & OLS & Heckman $2^{\text {nd }}$ step \\
& $(1)$ & $(2)$ \\
\hline Fraction of female directors & -0.010 & -0.015 \\
& $(0.055)$ & $(0.055)$ \\
High industry OC representation & -0.017 & -0.017 \\
& $(0.012)$ & $(0.012)$ \\
Fraction of female directors & $0.155^{* *}$ & $0.153^{* *}$ \\
$\quad \times$ High industry OC representation & $(0.075)$ & $(0.076)$ \\
Diversifying deal & -0.008 & -0.008 \\
& $(0.007)$ & $(0.007)$ \\
All equity & $-0.024^{* *}$ & $-0.024^{* *}$ \\
& $(0.010)$ & $(0.010)$ \\
Deal size & $-0.010^{* * *}$ & $-0.010^{* * *}$ \\
& $(0.003)$ & $(0.003)$ \\
Inverse Mills ratio & - & 0.034 \\
& & $(0.050)$ \\
& & \\
All controls & Yes & Yes \\
Industry effects & Yes & Yes \\
Year effects & Yes & Yes \\
Number of observations & 742 & 742 \\
Adjusted R & 0.082 & 0.081 \\
\hline
\end{tabular}


Table 9

Female board representation, overconfidence and corporate performance

This table contains regression models that examine the relation between female board representation, overconfidence and corporate performance/value. The dependent variables include Tobin's q, ROE (return on equity), and ROA (return on assets). The other control variables are the same as for regression (3) of Panel A in Table 3. Industry effects are constructed based on the Fama-French 49-industry classification. Statistical significance is based on the heteroskedasticity robust firm-clustered standard errors reported in parentheses. $* * *, * *$ and $*$ indicate significance at the $1 \%, 5 \%$ and $10 \%$ level, respectively.

\begin{tabular}{|c|c|c|c|c|c|c|}
\hline & \multicolumn{6}{|c|}{ Dependent variables } \\
\hline & \multicolumn{2}{|c|}{ Tobin's q } & \multicolumn{2}{|c|}{$\mathrm{ROE}$} & \multicolumn{2}{|c|}{$\mathrm{ROA}$} \\
\hline & $\begin{array}{l}\text { OLS } \\
(1)\end{array}$ & $\begin{array}{l}\text { Firm FE } \\
\text { (2) }\end{array}$ & $\begin{array}{l}\text { OLS } \\
(3)\end{array}$ & $\begin{array}{c}\text { Firm FE } \\
\text { (4) }\end{array}$ & $\begin{array}{c}\text { OLS } \\
(5)\end{array}$ & $\begin{array}{c}\text { Firm FE } \\
(6)\end{array}$ \\
\hline \multirow[t]{2}{*}{ Lagged ROE } & $0.795 * * *$ & $0.504 * * *$ & $0.561 * * *$ & $0.292 * * *$ & $0.800 * * *$ & $0.486 * * *$ \\
\hline & $(0.011)$ & $(0.023)$ & $(0.040)$ & $(0.054)$ & $(0.011)$ & $(0.024)$ \\
\hline \multirow{2}{*}{ Fraction of female directors } & -0.068 & -0.171 & -0.021 & 0.104 & 0.001 & $0.024 * *$ \\
\hline & $(0.083)$ & $(0.139)$ & $(0.047)$ & $(0.086)$ & $(0.008)$ & $(0.012)$ \\
\hline \multirow[t]{2}{*}{ High industry OC representation } & $-0.062 * * *$ & 0.005 & 0.002 & 0.005 & 0.000 & $0.006 * * *$ \\
\hline & $(0.020)$ & $(0.022)$ & $(0.008)$ & $(0.010)$ & $(0.002)$ & $(0.002)$ \\
\hline \multirow{2}{*}{$\begin{array}{l}\text { Fraction of female directors } \\
\quad \times \text { High industry OC representation }\end{array}$} & $0.412 * * *$ & $0.424 * * *$ & $0.189 * * *$ & $0.177 * *$ & $0.017 *$ & 0.002 \\
\hline & $(0.128)$ & $(0.144)$ & $(0.062)$ & $(0.075)$ & $(0.010)$ & $(0.012)$ \\
\hline All controls & Yes & Yes & Yes & Yes & Yes & Yes \\
\hline Industry effects & Yes & No & Yes & No & Yes & No \\
\hline Year effects & Yes & Yes & Yes & Yes & Yes & Yes \\
\hline Number of observations & 8,851 & 8,851 & 8,851 & 8,851 & 8,851 & 8,851 \\
\hline Adjusted $\mathrm{R}^{2}$ & 0.760 & 0.415 & 0.410 & 0.100 & 0.681 & 0.272 \\
\hline
\end{tabular}


Table 10

Female board representation and corporate performance during the recent financial crisis

This table presents the OLS regressions results of the change in firm performance (denoted as $\triangle T o b i n ' s q, \triangle R O A$, and $\triangle R O E$ ) and CEO option moneyness (denoted as $\triangle C E O$ option moneyness) from 2007 to 2009 on the severity of the house price collapse across firms with varying degrees of female board representation. The other control variables are the same as for regression (3) of Panel A in Table 3. All independent variables are measured in 2006. Industry effects are constructed based on the Fama-French 49-industry classification. Statistical significance is based on the heteroskedasticity robust firm-clustered standard errors reported in parentheses. $* * * * *$ and $*$ indicate significance at the $1 \%, 5 \%$ and $10 \%$ level, respectively.

\begin{tabular}{|c|c|c|c|c|}
\hline & \multicolumn{4}{|c|}{ Dependent variables } \\
\hline & $\begin{array}{c}\Delta \mathrm{CEO} \text { option moneyness } \\
(1)\end{array}$ & $\begin{array}{c}\Delta \text { Tobin's q } \\
\text { (2) }\end{array}$ & $\begin{array}{l}\triangle \mathrm{ROA} \\
\quad(3)\end{array}$ & $\begin{array}{l}\triangle \mathrm{ROE} \\
\quad(4)\end{array}$ \\
\hline Fraction of female directors & $\begin{array}{c}0.400 \\
(0.282)\end{array}$ & $\begin{array}{l}-0.259 \\
(0.320)\end{array}$ & $\begin{array}{l}-0.043 \\
(0.040)\end{array}$ & $\begin{array}{l}-0.125 \\
(0.104)\end{array}$ \\
\hline 4th Qtile House price shock & $\begin{array}{l}-0.096 * \\
(0.055)\end{array}$ & $\begin{array}{l}-0.084 * \\
(0.047)\end{array}$ & $\begin{array}{c}-0.016 * * \\
(0.007)\end{array}$ & $\begin{array}{c}-0.050 * * * \\
(0.018)\end{array}$ \\
\hline Fraction of female directors $\times 4$ th Qtile House price shock & $\begin{array}{l}0.667 * * \\
(0.323)\end{array}$ & $\begin{array}{l}-0.188 \\
(0.328)\end{array}$ & $\begin{array}{l}0.142 * * * \\
(0.045)\end{array}$ & $\begin{array}{l}0.329 * * \\
(0.127)\end{array}$ \\
\hline 1st Qtile House price shock & $\begin{array}{l}-0.138 \\
(0.089)\end{array}$ & $\begin{array}{c}0.025 \\
(0.050)\end{array}$ & $\begin{array}{l}-0.008 \\
(0.008)\end{array}$ & $\begin{array}{l}-0.035^{*} \\
(0.020)\end{array}$ \\
\hline Fraction of female directors $\times 1$ st Qtile House price shock & $\begin{array}{c}0.320 \\
(0.651)\end{array}$ & $\begin{array}{l}-0.653 \\
(0.432)\end{array}$ & $\begin{array}{c}0.036 \\
(0.059)\end{array}$ & $\begin{array}{c}0.098 \\
(0.148)\end{array}$ \\
\hline All controls & Yes & Yes & Yes & Yes \\
\hline Industry effects & Yes & Yes & Yes & Yes \\
\hline Number of bservations & 516 & 516 & 516 & 516 \\
\hline Adjusted $\mathrm{R}^{2}$ & 0.220 & 0.099 & 0.153 & 0.078 \\
\hline
\end{tabular}




\section{Appendix}

Variable definition

\begin{tabular}{ll}
\hline Variables & Description \\
\hline Main variables & \\
CEO option moneyness & We estimate the average CEO stock option moneyness for each year following Campbell et al. \\
& $(2011)$ and Hirshleifer et al. (2012). Specifically, we first calculate the average realizable value \\
& per option by dividing the total realizable value of the exercisable options by the number of \\
& exercisable options. Next, we subtract the average realizable value from the fiscal year-end \\
& stock price to obtain the average exercise price of the options. The estimated moneyness of the \\
& options is then calculated as the stock price divided by the estimated average exercise price \\
minus one.
\end{tabular}

Fraction of female directors

Fraction of male directors linked to female directors

Female-to-male population ratio

Female appointment

\section{Firm characteristics}

\section{$\operatorname{Ln}($ Sales $)$}

\section{Leverage}

Stock return

ROA

ROE
The ratio of the number of female directors on the board to board size.

The fraction of male directors on the board who sit on other boards with at least one female director.

The ratio of the female population to the male population in the state where the firm is headquartered for a given year.

An indicator variable that equals one if the firm appoint a female director, and zero otherwise.
Source

\section{ExecuComp}

\section{IRRC/RiskMetrics}

IRRC/RiskMetrics

US Economic

Census

IRRC/RiskMetrics
The natural logarithm of the firm's sales.

The sum of short-term and long-term debt divided by total assets.

The firm's stock return over the past year

Earnings before interest, taxes, depreciation, and amortization divided by total assets.

Earnings before interest, taxes, depreciation, and amortization divided by common equity.
Compustat

Compustat

CSRP

Compustat

Compustat 


\section{Variables}

Tobin's q

Description

The mark

divided by total assets, where the market value of equity is the year-end closing price times the number of stocks outstanding.

Board variables and other controls

Board independence

Board size

E index

No. external board seats

No. male external board seats

\section{CEO characteristics}

CEO age

CEO Chairman

CEO tenure

CEO ownership

MBA

Age first CEO role

Qualification

Military experience
The fraction of independent directors on the board.

IRRC/RiskMetrics

The number of directors on the board.

The Bebchuk et al. (2009) entrenchment index based on six antitakeover provisions: staggered boards, limits to shareholder bylaw amendments, poison pills, golden parachutes, supermajority requirements for mergers, and charter amendments. The index measures the number of antitakeover provisions in place.

The total number of external board seats by directors.

The total number of external board seats by male directors.

The age of the CEO in years.

An indicator variable that equals one if the CEO also chairs the board, and zero otherwise.

The fraction of the firm's stocks owned by the CEO.

An indicator variable that equals one if the CEO has an MBA degree, and zero otherwise.

The age at which the CEO became CEO for the first time.

An indicator variable that equals one if the CEO holds professional qualifications, and zero BoardEx otherwise.

An indicator variable that equals one if the CEO has prior military service, and zero otherwise.
IRRC/RiskMetrics

IRRC/RiskMetrics

ExecuComp

ExecuComp

ExecuComp

ExecuComp

BoardEx

BoardEx

IRRC/RiskMetrics

RiskMetrics,

BoardEx
The number of years the CEO has been in office. 


\section{Variables}

Ivy League

University, Columbia University, Cornell University, Dartmouth College, Harvard University,

Princeton University, University of Pennsylvania, and Yale University) at any academic level, and zero otherwise.

\section{Other variables}

Dummy_MBA replaces non-MBA

Dummy_Non-MBA replaces MBA

Dummy_Ivy replaces non-Ivy

Dummy_Non-Ivy replaces Ivy

Dummy_Qualif. replaces non-Qualif.

Dummy_Non-Qualif. replaces Qualif.

\section{Female appointment}

Post

Value ratio
An indicator variable that equals one if an incumbent director without an MBA degree is BoardEx replaced by a new director with an MBA degree, and zero otherwise.

An indicator variable that equals one if an incumbent director with an MBA degree is replaced BoardEx by a new director without an MBA degree, and zero otherwise.

An indicator variable that equals one if an incumbent director who did not attend an Ivy League BoardEx university is replaced by a new director who did, and zero otherwise.

An indicator variable that equals one if an incumbent director who attended an Ivy League BoardEx university is replaced by a new director who did not, and zero otherwise.

An indicator variable that equals one if an incumbent director without professional qualification is replaced by a new director with professional qualification, and zero otherwise.

An indicator variable that equals one if an incumbent director with professional qualification is replaced by a new director without professional qualification, and zero otherwise.

A dummy variable that equals one if the firm appoints a female director, and zero otherwise.

A dummy variable that equals one in the period after the appointment of a female director, and zero otherwise.

The ratio of the intrinsic value to the strike price of the option, where the intrinsic value is calculated as the stock price at exercise minus the strike price.
BoardEx

BoardEx

IRRC/RiskMetrics

IRRC/RiskMetrics

Thomson Reuters Insider Filings database 


\begin{tabular}{|c|c|c|}
\hline Variables & Description & Source \\
\hline Time to expiration & The remaining number of years until option expiration at exercise. & $\begin{array}{l}\text { Thomson Reuters } \\
\text { Insider Filings } \\
\text { database }\end{array}$ \\
\hline High industry OC representation & $\begin{array}{l}\text { A dummy variable that equals one if the fraction of overconfident CEOs for an industry in that } \\
\text { year is greater than the sample median across all industries and zero otherwise, where } \\
\text { overconfident CEOs are those who hold stock options that are more than } 67 \% \text { in the money. }\end{array}$ & ExecuComp \\
\hline Cash flow & $\begin{array}{l}\text { The sum of income before extraordinary items and depreciation, scaled by net plant, property } \\
\text { and equipment. }\end{array}$ & Compustat \\
\hline Capital expenditures & $\begin{array}{l}\text { The firm's capital expenditures in year } \mathrm{t}+1 \text { scaled by net property, plant and equipment in year } \\
\text { t. }\end{array}$ & Compustat \\
\hline Prior industry merger intensity & $\begin{array}{l}\text { The total number of merger deals in the industry within the past two years divided by the total } \\
\text { number of mergers across all industries over the same period. Industries are defined based on } \\
\text { the Fama-French } 49 \text {-industry classification. }\end{array}$ & SDC \\
\hline Diversifying deal & $\begin{array}{l}\text { A dummy variable that equals one if the bidder and target are in different two-digit SIC } \\
\text { industries, and zero otherwise. }\end{array}$ & SDC \\
\hline All equity & $\begin{array}{l}\text { A dummy variable that equals one if the method of payment was } 100 \% \text { equity, and zero } \\
\text { otherwise. }\end{array}$ & SDC \\
\hline Deal size & The natural logarithm of one plus the reported deal value. & SDC \\
\hline CAR $[-5,+5]$ & $\begin{array}{l}\text { The acquirer's cumulative abnormal returns from five days before the acquisition } \\
\text { announcement to five days after, where the abnormal returns are the market model residuals, } \\
\text { with the parameters estimated over the }[-205,-6] \text { window relative to the announcement day. }\end{array}$ & CRSP \\
\hline 4th Qtile House price shock & $\begin{array}{l}\text { An indicator variable for the fourth quartile (most severe) of House price shock, where House } \\
\text { price shock is the percentage drop in the Zillow Home Value Index (ZHVI) from December } \\
2006 \text { until December } 2009 \text { in the company's state of headquarters. }\end{array}$ & Zillow \\
\hline 1th Qtile House price shock & $\begin{array}{l}\text { An indicator variable for the first quartile (least severe) of House price shock, where House } \\
\text { price shock is the percentage drop in the Zillow Home Value Index (ZHVI) from December } \\
2006 \text { until December } 2009 \text { in the company's state of headquarters. }\end{array}$ & Zillow \\
\hline
\end{tabular}


Supporting Documentation for Manuscript

"Why Female Board Representation Matters: The Role of Female Directors in Reducing Male CEO Overconfidence in Corporate Decisions"

NOT FOR PUBLICATION

Results Available From the Authors on Request 


\section{Section 4.2.1. Alternative matching criteria}

This table examines the robustness of our results to the use of alternative matching criteria. CEO option moneyness is the CEO's estimated stock option moneyness. Fraction of female directors is the ratio of the number of female directors on the board to board size. Panels A to $\mathrm{C}$ present the average treatment effect estimates using alternative matching criteria. Panel D re-estimates the effect of female board representation on CEO option moneyness using matched samples. The other control variables are the same as for regression (3) of Panel A in Table 3. Industry effects are constructed based on the Fama-French 49-industry classification. Statistical significance is based on the heteroskedasticity robust firm-clustered standard errors reported in parentheses. $* * *, * *$ and * indicate significance at the $1 \%, 5 \%$ and $10 \%$ level, respectively.






\section{Section 4.3. Female board representation and CEO option exercise behavior}

This table contains the regressions that examine the relation between female board representation and the characteristics of the exercised options. The dependent variable in regressions (1) and (2) is Value ratio, which is defined as the ratio of the intrinsic value to the strike price of the option, where the intrinsic value is calculated as the stock price at exercise minus the strike price. The dependent variable in regressions (3) and (4) is Time to expiration, which is defined as the remaining number of years until option expiration at exercise. Both Value ratio and Time to expiration are aggregated for each CEO on an annual basis, using a simple average over the number of options exercised. CEO-years without option exercises are omitted from the analysis. Fraction of female directors is the number of female directors divided by board size. The control variables are the same as for regression (3) of Panel A in Table 3. For the sake of brevity, we report only the coefficients on the main variable of interest. Industry effects are constructed based on the Fama-French 49-industry classification. Statistical significance is based on the heteroskedasticity robust firm-clustered standard errors reported in parentheses. ***, $* *$ and $*$ indicate significance at the $1 \%, 5 \%$ and $10 \%$ level, respectively.

\begin{tabular}{lccccc}
\hline & \multicolumn{4}{c}{ Dependent variables } \\
\cline { 2 - 5 } & \multicolumn{2}{c}{ Value ratio } & & \multicolumn{2}{c}{ Time to expiration } \\
\cline { 2 - 4 } & OLS & Firm FE & & OLS & Firm FE \\
& $(1)$ & $(2)$ & & $(3)$ & $(4)$ \\
\cline { 2 - 3 } \cline { 5 - 6 } Fraction of female directors & $-1.584^{* *}$ & $-1.753^{* *}$ & & $0.560^{*}$ & $0.445^{*}$ \\
& $(0.783)$ & $(0.868)$ & & $(0.306)$ & $(0.258)$ \\
All controls & & & & & \\
Industry effects & Yes & Yes & & Yes & Yes \\
Year effects & Yes & No & & Yes & No \\
Number of observations & Yes & Yes & & Yes & Yes \\
Adjusted R $\mathrm{R}^{2}$ & 8,380 & 8,380 & & 8,427 & 8,427 \\
& 0.138 & 0.148 & & 0.087 & 0.067 \\
\hline
\end{tabular}




\section{Section 7. Alternative constructs of the female director variable}

This table examines the relationship between female board representation and CEO option moneyness using alternative constructs of the female director variable. The dependent variable is the CEO's stock option moneyness (CEO option moneyness). Female directors is an indicator variable that equals one if there is at least one female director on the board, and zero otherwise. Multiple female directors is an indicator variable that equals one if there is more than one female director on the board, and zero otherwise. Female committee members is an indicator variable that equals one if there is at least one female director with committee membership(s), and zero otherwise. Female $C F O$ is an indicator variable that equals one if the CFO is a female, and zero otherwise. Variable definitions are provided in the Appendix. The other control variables are the same as for regression (3) of Panel A in Table 3. Industry effects are constructed based on the Fama-French 49-industry classification. Statistical significance is based on the heteroskedasticity robust firm-clustered standard errors reported in parentheses. ***, $* *$ and $*$ indicate significance at the $1 \%, 5 \%$ and $10 \%$ level, respectively.

\begin{tabular}{|c|c|c|}
\hline \multirow{4}{*}{ Female directors } & \multicolumn{2}{|c|}{ Dependent variable: CEO option moneyness } \\
\hline & (1) & (2) \\
\hline & $-0.091 * * *$ & $0.083^{*}$ \\
\hline & $(0.035)$ & $(0.045)$ \\
\hline Multiple female directors & $-0.080 * *$ & - \\
\hline & $(0.032)$ & \\
\hline Female committee members & - & $\begin{array}{c}-0.139 * * \\
(0.061)\end{array}$ \\
\hline Female CFO & - & $\begin{array}{l}-0.145^{*} \\
(0.082)\end{array}$ \\
\hline All controls & Yes & Yes \\
\hline Industry effects & Yes & Yes \\
\hline Year effects & Yes & Yes \\
\hline Number of observations & 11,113 & 10,779 \\
\hline Adjusted $\mathrm{R}^{2}$ & 0.224 & 0.227 \\
\hline
\end{tabular}




\section{Section 7. Managerial overconfidence and investment-cash flow sensitivity}

This table contains regression models that examine the relation between managerial overconfidence and investment cash flows sensitivity. The dependent variable, Capital expenditures, is defined as the firm's capital expenditures in year $t+1$ scaled by net property, plant and equipment in year $t$. Variable definitions are provided in the Appendix. The other control variables are the same as for regression (3) of Panel A in Table 3. Industry effects are constructed based on the Fama-French 49-industry classification. Statistical significance is based on the heteroskedasticity robust firm-clustered standard errors reported in parentheses. ***,** and * indicate significance at the $1 \%, 5 \%$ and $10 \%$ level, respectively.

\begin{tabular}{lcc}
\hline & Dependent variable: Capital expenditures (CAPEX $\left.{ }_{\mathrm{t}+1} / \mathrm{PPE}_{\mathrm{t}}\right)$ \\
\cline { 2 - 3 } & OLS & Firm FE \\
& $(1)$ & $(2)$ \\
\hline Lagged capital expenditures & $0.499^{* * *}$ & $\left(0.023^{* * *}\right.$ \\
& $(0.018)$ & $0.236^{* * *}$ \\
Cash flow & $0.074^{* * *}$ & $(0.034)$ \\
& $(0.024)$ & $0.012^{* *}$ \\
CEO option moneyness & $0.019^{* * *}$ & $(0.005)$ \\
& $(0.004)$ & $0.025^{*}$ \\
Cash flow $\times$ CEO option moneyness & $0.036^{*}$ & $(0.014)$ \\
& $(0.021)$ & \\
All controls & & Yes \\
Industry effects & Yes & No \\
Year effects & Yes & Yes \\
Number of observations & Yes & 8,804 \\
Adjusted $\mathrm{R}^{2}$ & 8,804 & 0.194 \\
\hline
\end{tabular}




\section{Section 7. Female board representation and CEO option moneyness with additional controls}

This table examines the relationship between female board representation and CEO option moneyness with additional controls. The dependent variable is the CEO's stock option moneyness (CEO option moneyness). Fraction of female directors is the ratio of the number of female directors on the board to board size. Volatility is the annualized standard deviation of monthly stock return over the past year. $\operatorname{Ln}(1+$ Delta $)$ is the natural logarithm of one plus CEO delta, where delta is defined as the change in the value of the CEO's wealth due to a $1 \%$ increase in the firm's stock price. $\operatorname{Ln}(1+\mathrm{Vega})$ is the natural logarithm of one plus CEO vega, where vega is defined as the change in the value of the CEO's wealth due to a 0.01 increase in the annualized standard deviation of the firm's stock return. Variable definitions are provided in the Appendix. The other control variables are the same as for regression (3) of Panel A in Table 3. Industry effects are constructed based on the Fama-French 49-industry classification. Statistical significance is based on the heteroskedasticity robust firm-clustered standard errors reported in parentheses. The t-statistics for the Fama-MacBeth regressions are computed using the NeweyWest standard errors. $* * * * *$ and $*$ indicate significance at the $1 \%, 5 \%$ and $10 \%$ level, respectively.

\begin{tabular}{lcc}
\hline & \multicolumn{2}{c}{ Dependent variable: CEO option moneyness } \\
\cline { 2 - 3 } & OLS & Firm FE \\
\cline { 2 - 3 } Fraction of female directors & $(1)$ & $(2)$ \\
\cline { 2 - 3 } Volatility & $-0.308^{*}$ & $-0.536^{* *}$ \\
& $(0.162)$ & $(0.242)$ \\
$\ln (1+$ Vega $)$ & $0.171^{* *}$ & $0.443^{* * *}$ \\
& $(0.075)$ & $(0.094)$ \\
$\ln (1+$ Delta $)$ & $-0.273^{* * *}$ & $-0.207^{* * *}$ \\
& $(0.022)$ & $(0.023)$ \\
& $0.333^{* * *}$ & $0.186^{* * *}$ \\
All controls & $(0.024)$ & $(0.027)$ \\
Industry FE & & \\
Year FE & Yes & Yes \\
Observations & Yes & No \\
Adjusted R-squared & Yes & Yes \\
\hline
\end{tabular}




\section{Section 7. Robustness check: Are the results driven by a few very vocal female directors?}

This table examines whether the findings are driven by a few very vocal female directors. The dependent variable is the CEO's stock option moneyness (CEO option moneyness). Fraction of female directors is the ratio of the number of female directors on the board to board size. Variable definitions are provided in the Appendix. The other control variables are the same as for regression (3) of Panel A in Table 3. Industry effects are constructed based on the Fama-French 49-industry classification. Statistical significance is based on the heteroskedasticity robust firm-clustered standard errors reported in parentheses. The t-statistics for the Fama-MacBeth regressions are computed using the Newey-West standard errors. $* * *, * *$ and $*$ indicate significance at the $1 \%, 5 \%$ and $10 \%$ level, respectively.

\begin{tabular}{lcccc}
\hline & \multicolumn{4}{c}{$\begin{array}{c}\text { Exclude firm-years where at least one female director } \\
\text { has more than ... }\end{array}$} \\
\cline { 2 - 5 } & $\begin{array}{c}\text { 6 directorships } \\
(1)\end{array}$ & $\begin{array}{c}5 \text { directorships } \\
(2)\end{array}$ & $\begin{array}{c}4 \text { directorships } \\
(3)\end{array}$ & $\begin{array}{c}3 \text { directorships } \\
(4)\end{array}$ \\
\hline Fraction of female directors & $-0.620^{* * *}$ & $-0.636^{* * *}$ & $-0.603 * * *$ & $-0.579^{* * *}$ \\
& $(0.170)$ & $(0.174)$ & $(0.183)$ & $(0.206)$ \\
All controls & & & & \\
Industry effects & Yes & Yes & Yes & Yes \\
Year effects & Yes & Yes & Yes & Yes \\
Number of observations & Yes & Yes & Yes & Yes \\
Adjusted $\mathrm{R}^{2}$ & 10,587 & 10,258 & 9,465 & 8,113 \\
\hline
\end{tabular}

\section{Section 7. Alternative explanations and further robustness tests}

\begin{tabular}{|c|c|c|c|c|c|c|}
\hline & \multicolumn{6}{|c|}{ Dependent variable: } \\
\hline & \multicolumn{3}{|c|}{ Net buyer indicator } & \multicolumn{3}{|c|}{ Share retainer indicator } \\
\hline & $\begin{array}{l}\text { OLS } \\
(1)\end{array}$ & $\begin{array}{l}\text { Firm FE } \\
\text { (2) }\end{array}$ & $\begin{array}{l}\text { Logit } \\
\text { (3) }\end{array}$ & $\begin{array}{l}\text { OLS } \\
(4)\end{array}$ & $\begin{array}{c}\text { Firm FE } \\
(5)\end{array}$ & $\begin{array}{l}\text { Logit } \\
(6)\end{array}$ \\
\hline Fraction of female directors & $\begin{array}{l}-0.052 \\
(0.044)\end{array}$ & $\begin{array}{c}-0.105^{*} \\
(0.063)\end{array}$ & $\begin{array}{c}-0.716^{* * *} \\
(0.342)\end{array}$ & $\begin{array}{l}-0.227 * \\
(0.127)\end{array}$ & $\begin{array}{l}-0.107 \\
(0.167)\end{array}$ & $\begin{array}{l}-1.022^{*} \\
(0.565)\end{array}$ \\
\hline All controls & Yes & Yes & Yes & Yes & Yes & Yes \\
\hline Industry effects & Yes & No & Yes & Yes & No & Yes \\
\hline Year effects & Yes & Yes & Yes & Yes & Yes & Yes \\
\hline Number of observations & 11,113 & 11,113 & 11,113 & 6,755 & 6,755 & 6,755 \\
\hline Adjusted $\mathrm{R}^{2} /$ Pseudo $\mathrm{R}^{2}$ & 0.043 & 0.024 & 0.084 & 0.073 & 0.029 & 0.064 \\
\hline
\end{tabular}




\section{Section 7. Alternative explanations and further robustness tests}

Panel A. Excluding firm-years with CEO turnovers

\begin{tabular}{lcc}
\hline & \multicolumn{2}{c}{ Dependent variable: CEO option moneyness } \\
\cline { 2 - 3 } & OLS & Firm fixed effects \\
& $(1)$ & $-0.676^{* * *}$ \\
& $-0.643^{* * *}$ & $(0.249)$ \\
& $(0.172)$ & \\
Fraction of female directors & & Yes \\
All controls & Yes & No \\
Industry FE & Yes & Yes \\
Year FE & Yes & 10,589 \\
Number of observations & 10,589 & 0.201 \\
Adjusted $\mathrm{R}^{2}$ & 0.226 & \\
\hline
\end{tabular}

Panel B. Excluding recession periods 2001-2002 and 2007-2009

Dependent variable: CEO option moneyness

\begin{tabular}{cc}
\hline OLS & Firm fixed effect \\
$(1)$ & $(2)$ \\
$-0.677^{* * *}$ & $-0.569^{* *}$ \\
$(0.199)$ & $(0.282)$
\end{tabular}

\begin{tabular}{lcc} 
All controls & Yes & Yes \\
Industry FE & Yes & No \\
Year FE & Yes & Yes \\
Number of observations & 7,578 & 7,578 \\
Adjusted $\mathrm{R}^{2}$ & 0.233 & 0.201 \\
\hline
\end{tabular}


Panel C. OLS regression results with alternative clustering

\begin{tabular}{lccc}
\hline & \multicolumn{3}{c}{ Dependent variable: CEO option moneyness } \\
\cline { 2 - 4 } & By year & By industry & By firm and year \\
& $(1)$ & $(2)$ & $-0.627^{* * *}$ \\
\hline Fraction of female directors & $-0.627^{* * *}$ & $-0.627^{* * *}$ & $(0.172)$ \\
& $(0.116)$ & $(0.161)$ & \\
& & & Yes \\
All controls & Yes & Yes & Yes \\
Industry effects & Yes & Yes & Yes \\
Year effects & Yes & Yes & 11,113 \\
Number of observations & 11,113 & 11,113 & 0.229 \\
Adjusted R & 0.224 & 0.224 & \\
\hline
\end{tabular}

Panel D. OLS regression results with alternative definitions of industry effects

\begin{tabular}{|c|c|c|c|c|}
\hline & \multicolumn{4}{|c|}{ Dependent variable: CEO option moneyness } \\
\hline & $\begin{array}{c}\text { SIC2 } \\
\text { industries } \\
(1)\end{array}$ & $\begin{array}{l}\text { NAICS3 } \\
\text { industries } \\
\quad(2)\end{array}$ & $\begin{array}{c}\text { FF49 industries } \\
\text { without year effects } \\
\text { (3) }\end{array}$ & $\begin{array}{l}\text { FF49×Year } \\
\text { effects } \\
(4)\end{array}$ \\
\hline Fraction of female directors & $\begin{array}{c}-0.619 * * * \\
(0.165)\end{array}$ & $\begin{array}{c}-0.650^{* * * *} \\
(0.164)\end{array}$ & $\begin{array}{c}-0.658^{* * * *} \\
(0.168)\end{array}$ & $\begin{array}{c}-0.648^{* * * *} \\
(0.165)\end{array}$ \\
\hline All controls & Yes & Yes & Yes & Yes \\
\hline Industry effects & Yes & Yes & Yes & No \\
\hline Year effects & Yes & Yes & No & No \\
\hline Industry $\times$ Year effects & No & No & No & Yes \\
\hline Number of observations & 11,113 & 11,113 & 11,113 & 11,113 \\
\hline Adjusted $\mathrm{R}^{2}$ & 0.228 & 0.228 & 0.198 & 0.269 \\
\hline
\end{tabular}


